OPEN ACCESS

Edited by: Makoto Tokuda,

Saga University, Japan

Reviewed by:

Torsten Wappler,

Hessisches Landesmuseum

Darmstadt, Germany

Diane Erwin,

University of California Museum

of Paleontology, United States

*Correspondence:

Conrad C. Labandeira labandec@si.edu

Specialty section:

This article was submitted to

Paleoecology,

a section of the journa

Frontiers in Ecology and Evolution

Received: 09 December 2020

Accepted: 26 April 2021

Published: 17 June 2021

Citation:

Labandeira CC (2021) Ecology and Evolution of Gall-Inducing Arthropods: The Pattern From the Terrestrial Fossil Record.

Front. Ecol. Evol. 9:632449. doi: $10.3389 /$ fevo.2021.632449

\section{Ecology and Evolution of Gall-Inducing Arthropods: The Pattern From the Terrestrial Fossil Record}

\author{
Conrad C. Labandeira ${ }^{1,2,3 *}$ \\ ${ }^{1}$ Department of Paleobiology, National Museum of Natural History, Smithsonian Institution, Washington, DC, United States, \\ ${ }^{2}$ Department of Entomology, University of Maryland, College Park, College Park, MD, United States, ${ }^{3}$ College of Life \\ Sciences, Academy for Multidisciplinary Studies, Capital Normal University, Beijing, China
}

Insect and mite galls on land plants have a spotty but periodically rich and abundant fossil record of damage types (DTs), ichnotaxa, and informally described gall morphotypes. The earliest gall is on a liverwort of the Middle Devonian Period at 385 million years ago (Ma). A 70-million-year-long absence of documented gall activity ensues. Gall activity resumes during the Pennsylvanian Period ( $315 \mathrm{Ma}$ ) on vegetative and reproductive axial organs of horsetails, ferns, and probably conifers, followed by extensive diversification of small, early hemipteroid galler lineages on seed-plant foliage during the Permian Period. The end-Permian (P-Tr) evolutionary and ecological crisis extinguished most gall lineages; survivors diversified whose herbivore component communities surpassed pre-P-Tr levels within 10 million years in the mid-to late Triassic (242 Ma). During the late Triassic and Jurassic Period, new groups of galling insects colonized Ginkgoales, Bennettitales, Pinales, Gnetales, and other gymnosperms, but data are sparse. Diversifying mid-Cretaceous (125-90 Ma) angiosperms hosted a major expansion of 24 gall DTs organized as herbivore component communities, each in overlapping Venn-diagram fashion on early lineages of Austrobaileyales, Laurales, Chloranthales, and Eurosidae for the Dakota Fm (103 Ma). Gall diversification continued into the Ora Fm (92 Ma) of Israel with another 25 gall morphotypes, but as ichnospecies on a different spectrum of plant hosts alongside the earliest occurrence of parasitoid attack. The End-Cretaceous (K-Pg) extinction event (66 Ma) almost extinguished hostspecialist DTs; surviving gall lineages expanded to a pre-K-Pg level 10 million years later at the Paleocene-Eocene Thermal Maximum (PETM) (56 Ma), at which time a dramatic increase of land surface temperatures and multiplying of atmospheric $\mathrm{pCO}_{2}$ levels induced a significant level of increased herbivory, although gall diversity increased only after the PETM excursion and during the Early Eocene Climatic Optimum (EECO). After the EECO, modern (or structurally convergent) gall morphotypes originate in the mid-Paleogene (49-40 Ma), evidenced by the Republic, Messel, and Eckfeld floras on hosts different from their modern analogs. During subsequent global aridification, the early Neogene (20 Ma) Most flora of the Czech Republic records several modern 
associations with gallers and plant hosts congeneric with their modern analogs. Except for 21 gall DTs in New Zealand flora, the gall record decreases in richness, although an early Pleistocene ( $3 \mathrm{Ma}$ ) study in France documents the same plant surviving as an endemic northern Iran but with decreasing associational, including gall, host specificity.

Keywords: angiosperms, damage types, end-Cretaceous extinction, end-Permian extinction, insects, mites, PETM, seed plants

The great antiquity of galls may be taken as evidence that gall-inducing insects. . continually exploit their host plants, despite numerous mechanisms by which plants can deter insect feeding.

Miller and Raman (2019), p. 2

\section{INTRODUCTION}

Galls are variously shaped, three-dimensional growths of plants consisting of highly modified tissues which are caused by diverse organisms (Darlington, 1975; Dreger-Jauffret and Shorthouse, 1992; Westphal, 1992; Redfern et al., 2002; Redfern, 2011). Each of these anomalous plant structures represents an extended phenotype that is under the metabolic control of a gallinducing organism, typically a mite or insect (Meyer, 1969; Stone and Schönrogge, 2003; Álvarez et al., 2013; Nagler and Haug, 2015; Giron et al., 2016). The extended phenotype of the galling insect results in production of atypically formed and positioned tissues that are hardened, are mostly three-dimensional, and resistant to flattening (Scott et al., 1994; but see Larew, 1992). These physical features of galls fortunately allow their preservation in the fossil record and provide a basis for evaluating their external and occasionally internal structure (Labandeira et al., 2007). Notably, gall morphology not only is used to morphotype fossil galls but also categorizes modern galls into morphotypes (Maia and Fernandes, 2004; Formiga et al., 2011; Isaias et al., 2014). The assignment of modern galls into morphotypes has been used productively to distinguish species of thrips (McLeish et al., 2006), aphids (Stern, 1995), and tenthredinid sawflies (Nyman, 2000).

During the past four decades, a considerable amount of data has been garnered to document the fossil history of insect and mite galls (Wittlake, 1969, 1981; Larew, 1986, 1992; Stephenson, 1991; Scott et al., 2004) as a result of the broader study of examining plant-insect interactions that extends to a 385-million-year-long interval from the Recent (Carvalho et al., 2014) to Middle Devonian (Labandeira et al., 2014). Important fossil deposits occurring during this intervening time contain several floras with diverse galls that include, for the Paleozoic, the latest Pennsylvanian Williamson Drive flora of the Markley Formation (Fm) from Texas, United States (Xu et al., 2018), and the early Permian Colwell Creek Pond flora of the Middle Clear Fork Fm from Texas, United States (Schachat et al., 2015). For the Mesozoic, the latest Early Cretaceous Rose Creek flora of the Dakota Fm from Nebraska, United States has
24 distinct gall types (Xiao and Labandeira, 2020: personal observation). For the Cenozoic, there is the earliest Paleogene Palacios de los Loros 2 flora of the Salamanca Fm from Patagonia, Argentina (Donovan et al., 2016, 2018); the midPaleogene Republic flora of the Klondike Mountain Fm from Washington state, United States (Labandeira, 2002); and especially the 36 distinctive galls of the mid-Paleogene Messel flora of the Messel Fm from Hesse, Germany (Wappler et al., 2012; Dunne et al., 2014). While each of these localities have elevated abundances of galls in deep time, there is also considerable throughput of single or at most a few gall occurrences in numerous deposits throughout the fossil record.

In this review, the fossil gall record is evaluated using three approaches that have been used in the primary literature to characterize galls. The first approach, historically the oldest, employs descriptions of galls as they were encountered in studies of fossil floras (Wittlake, 1981; Larew, 1986; Scott et al., 1994; Skuhravá and Skuhravý, 2009). Such descriptions of galls were made often by paleobotanists that noticed unusual structures on fossil (Mei et al., 1992) plants that could not be explained by known traits of plants (Van Amerom, 1973; Hickey and Doyle, 1977; Ash, 1997) but were consistent with known gall structures. Alternatively, gall-like structures originally were described on plants as botanical structures, such as putative bennettitalean microsporophylls (Harris, 1942), pitchers of pitcher plants (Li, 2005), and seeds on a seed-fern leaf (Mamay, 1960), which upon reanalysis, were deemed galls, respectively, by Alvin et al. (1967), Stull et al. (2013), and Wong et al. (2015). The second approach, of more recent vintage, is to assess the fossil gall record using the ichnotaxonomic fossil record, in which galls are formally classified as trace fossils in a procedure paralleling a Linnaean classification system (Ride et al., 1985; Rindsberg, 1990; Maslova et al., 2016; Enuschchenko and Frolov, 2020). Consequently, ichnogenera and ichnospecies can be described, often under the taxonomic family Paleogallidae (e.g., Stull et al., 2013), although the formal status of this ichnofamily is questioned by some (Genise et al., 2004). The third approach evaluates informal plant damage, such as galls, under the damage type (DT)-functional feeding group system in which distinctive gall morphotypes are assigned DT numbers (Wilf and Labandeira, 1999; Labandeira et al., 2007; Currano, 2019) that can be used later in quantitative paleoecological analyses. Each of these three approaches will be used to understand the paleobiology of galls and their galler insects in the 17 relevant intervals of time mentioned below (Table 1). 
TABLE 1 | Overview of important events in the evolution of terrestrial galls.

\begin{tabular}{|c|c|c|c|}
\hline Text topic & Major gall-related event & Geologic timeline & Principal Biogeographic localities \\
\hline 1 & Origin of galls on an early cryptogam & Middle Devonian & Euramerica \\
\hline 2 & $\begin{array}{l}\text { Unknown Interval: Gall expansion on early vascular } \\
\text { plants }\end{array}$ & Middle Devonian-latest Mississippian & Euramerica \\
\hline 3 & Axial galls on horsetails, ferns and coniferophytes & Pennsylvanian & Euramerica \\
\hline 4 & Expansion onto seed-plant foliage & Permian & Euramerica \\
\hline 5 & Permian-Triassic ecologic and evolutionary Crisis & P-Tr boundary & Euramerica, Cathaysia \\
\hline 6 & $\begin{array}{l}\text { Triassic recuperation following the Permian-Triassic } \\
\text { event }\end{array}$ & Middle to Late Triassic & Euramerica, Gondwana \\
\hline 7 & $\begin{array}{l}\text { Colonization of seedferns, bennettitaleans, and other } \\
\text { gymnosperms }\end{array}$ & Jurassic & Cathaysia, North America \\
\hline 8 & Expansion onto early angiosperm lineages & Early Cretaceous & North America \\
\hline 9 & $\begin{array}{l}\text { Cretaceous-Paleogene ecologic and Evolutionary } \\
\text { crisis }\end{array}$ & K-Pg boundary interval & North America, South America \\
\hline 10 & Initial recovery from the Cretaceous-Paleogene event & Earliest Paleogene & North America, South America, Europe \\
\hline 11 & $\begin{array}{l}\text { Delayed recovery from the Cretaceous-Paleogene } \\
\text { event }\end{array}$ & Early Paleogene & North America, Europe \\
\hline 12 & Effect of the Paleocene-Eocene Thermal Maximum & Paleocene-Eocene boundary interval & North America \\
\hline 13 & Response to the Early Eocene Climatic Optimum & Earlier mid Paleogene & North America \\
\hline 14 & Origin of many modern gall associations & Later mid Paleogene & Europe \\
\hline 15 & Role of global aridification on galler diversity & Late Paleogene & Europe \\
\hline 16 & Response to the global expansion of Grasslands & Neogene & Europe, New Zealand \\
\hline 17 & Hothouse-Icehouse cycles and the modern World & Latest Neogene & Europe \\
\hline
\end{tabular}

\section{MATERIALS AND METHODS}

The focus of this review is documentation of the fossil history of galls by the damage type-functional feeding group (DTFFG) system of analysis (Labandeira et al., 2007) that was established and first used by Wilf and Labandeira in 1999 and subsequently expanded for use in about 85 publications as of the end of 2020. This system characterizes herbivore damage on plants in the fossil and modern records by establishing broad categories of functional feeding groups based on modes of feeding and mouthpart structure. Within each FFG are the fundamental entities of herbivory, the damage types (DTs) that are diagnosable and well-defined patterns of insect, mite and fungal damage on plants, and importantly provide the qualitative and quantitative units of analysis of plant-insect interactions in the fossil record. There are 12 functional feeding groups, based on exophytic damage on plants (the hole feeding, margin feeding, skeletonization, and surface feeding FFGs), intermediate damage whereby the interactive elements of mouthparts and ovipositor are internal and insect body external to the plant (oviposition and piercing and sucking FFGs), endophytic damage (mining, galling, seed predation, borings, and domatia FFGs), and a fourth category (the pathogen FFG). While oviposition is technically not a feeding group, it is included in the DT-FFG system as it is well represented in the fossil record and is analogous in many ways to piercing-and-sucking damage.

The gall DTs documented in the recent update (late 2020) to Version 3 of the Guide to Insect (and Other) Damage Types on Compressed Plant Fossils (Labandeira et al., 2007)heretofore referred to as the Insect Damage Guide-includes earlier documentation for fossil gall DT occurrences (Ash, 1972, 1997; Van Amerom, 1973; Hickey and Doyle, 1977; Lewis, 1985; Grauvogel-Stamm and Kelber, 1996; Wilf et al., 2005) and was followed by addenda that document DT occurrences after the 2007 publication date (Currano et al., 2008, 2010; Krassilov, 2008; Krassilov et al., 2008; Wappler et al., 2009, 2012; Stull et al., 2013; Schachat et al., 2014, 2015; Ding et al., 2015; Schachat and Labandeira, 2015; Wong et al., 2015; Herrera et al., 2017; Donovan et al., 2018, 2020; Labandeira et al., 2018; Xu et al., 2018; Carvalho et al., 2021; also Xiao and Labandeira, 2020: personal observation). The Insect Damage Guide lists 407 DTs, of which 93 (22.9\%) are galls. By comparison, miners-the other major FFG of endophytic herbivory-consist of 78 DTs (19.2\%) and represent the second highest recorded FGG next to galls. Gall DTs in the latest version of the Insect Damage Guide have been characterized as to their external form within the galling FFG and comprise 12 categories. They are blister galls (22.6\%), erineum galls $(17.2 \%)$, covering galls (16.1\%), pouch galls $(11.8 \%)$, mark galls $(6.5 \%)$, bud galls (4.3\%), roll and fold galls (4.3\%), spangle galls (4.3\%), abscission holes of deciduous galls (4.3\%), armored scale galls (3.2\%), undifferentiated pit, mark or blister galls (3.2\%), and pit galls (2.2\%) (Mani, 1964, 1992; Larew, 1982; Chinery, 2011).

Host specificity is an important feature of the gall fossil record, and the distribution of galls on plant hosts within a flora is categorized as level 1 (generalized), level 2 (intermediate), and level 3 (specialized). In the fossil record, host specificity is determined largely in a similar way it is in the modern record, where generalized host specificity (polyphagy) consists of occurrences on multiple, unrelated plant hosts; intermediate host specificity (oligophagy) occurs on more distantly related host-plant species within the same larger clade such as a family; and specialized host specificity (monophagy) is restricted to one or multiple very closely related host-plant species. Gall host specificity values for the Insect Damage Guide indicates that $11.8 \%$ are generalized, $24.7 \%$ are of intermediate specificity, and 
$63.4 \%$ are specialized. However, such assignments are relevant for a given flora; for example, a DT85 gall in one flora may register as a level 2 (intermediate) host-plant specificity and yet the same DT may have a level 3 (specialized) specificity in another flora removed in time and space. These levels seem to be consistent with levels of host-plant specificity in modern galls (Espírito-Santo and Fernandes, 2007; Araújo, 2013).

The distribution of geologic time intervals for gall DTs in the Insect Damage Guide shows not only the vagaries of the fossil record, where preservation of well-documented floras is not distributed evenly throughout time, but more importantly, anthropogenic bias that predilects for the study of particular floras (Pinheiro et al., 2016). Of the 93 gall DTs in the Insect Damage Guide, 2.2\% are represented for the Pennsylvanian Period, $14.0 \%$ for the Permian Period, $10.8 \%$ for the Triassic Period, $2.2 \%$ for the Jurassic Period, $17.2 \%$ for the Cretaceous Period, 52.7\% for the Paleogene Period, and $1.1 \%$ for the Neogene Period. Much of this distribution reflects exploration of fossil floras that spotlight interesting questions at particular time intervals. These studies include the expansion of folivory, including gall associations, on early emerging seed-plant lineages in Permian of north-central Texas (Schachat et al., 2014, 2015; Schachat and Labandeira, 2015; Xu et al., 2018; Maccracken and Labandeira, 2020), a comparison of herbivory patterns, including gall DT diversity, on late-appearing gymnosperm floras of China relative to subsequent patterns on early emergent angiosperm floras of the United States (Xiao and Labandeira, 2020: personal observation), and documenting numerous gall DTs with modern analogs from the mid-Paleogene in Messel, Germany.

Another way of assessing the fossil gall DT record from the Insect Damage Guide is to record the distribution of the 93 gall DTs on major groups of vascular plants. Of the major plant groups, $3.2 \%$ are on sphenophytes (horsetails), $1.1 \%$ on pteridophytes (ferns), $36.6 \%$ on gymnosperms (cone bearing plants), $55.9 \%$ on angiosperms (flowering plants), and 3.2\% on plants of other or unknown taxonomic attribution. Almost all of the plant-host taxa that harbor gall DTs in the fossil record are extinct; some remnant taxa of the Cenozoic have persisted to the present.

It is within this framework of gall DTs that the fossil history of galls will be evaluated below. Where the DT gall fossil record is sparse, it will be supplemented by contributions from the traditional fossil record of gall descriptions and the ichnotaxonomic record of galls. Perhaps the greatest limitations of the data involve long time gaps, particularly a 60-millionyear-long interval from the mid-Devonian to the MississippianPennsylvanian boundary, the first 6 or 7 million years of the Triassic, much of the Late Cretaceous, and ironically the last 2 million years.

\section{RESULTS}

The results are presented as a linear, time series of 17 events, starting with the earliest known terrestrial galls during the Middle Devonian and ending in the most recent episode of gall response to hothouse-icehouse conditions of the past 3 million years.
The events associated with the evolution of galls in terrestrial ecosystems is described in the associated tables and figures of this contribution.

\section{The Paleozoic Era}

The evolution of the galler life habit (Roskam, 1992) commences during the Middle Devonian on cryptogam hosts. The process presumably spread to diminutive vascular plants such as fern relatives and the earliest arborescent plants, although the evidence for this is virtually non-existent. During the Pennsylvanian, there is evidence that spore-bearing plants of horsetails and ferns possessed galls along their vegetative and reproductive axes, but not on foliage. Soon thereafter, during the Permian, leaves of seed plants become the organs that were subject to gall insect attack. Most of the gall interactions with seed plants come to a dramatic end during the end-Permian ecologic crisis and extinction, only to reappear later in the succeeding Triassic (Figure 1; Supplementary Appendix 1).

\section{Origin of Galls on an Early Cryptogam (1)}

The earliest and most diverse evidence for terrestrial herbivory, the consumption of live tissues by arthropods, comes from the Rhynie Chert, in Scotland, of Early Devonian age. The three best examples from this hot spring deposit are piercing and sucking and pith borings on stems (Kevan et al., 1975), and the consumption of spores (Habgood et al., 2003) of early vascular plants that belong to extinct lineages. However, it is not until 25 million years later that the earliest gall is documented (Labandeira et al., 2014), from an anatomically preserved, foliose liverwort from the Plattekill Fm of New York state, in an environment of black shale and siltstone surrounding a pond or small lake whose plants were deposited subaqueously and were anoxically sealed to permit superb preservation. The liverwort, Metzergaliothallus sharonae, is represented by leaf-like gametophytic thalli, that contain a variety of herbivory that is small in size, and consists of nine DTs of hole feeding, margin feeding, surface feeding, piercing and sucking, and galling. The gall, DT32 (Figure 1, Plattekill), is a simple, ellipsoidal, and apparently single-chambered gall that displays tissue hyperplasy and internal cell-wall thickenings, and possesses a distinctive outer wall (Labandeira et al., 2014). The galls avoid terpenoidladen oil cells, typical of liverworts, that may indicate an early defense mechanism by the host plant.

\section{Unknown Interval: Gall Expansion on Early Vascular Plants? (2)}

An approximately 60-million-year-long gap occurred between the earliest galls present on cryptograms at $385 \mathrm{Ma}$ (Labandeira et al., 2014) and the appearance of galls on spore-bearing plants at $325 \mathrm{Ma}$. This is a time interval that is mirrored by other plant-insect interactions that were consummated long after the appearance of the relevant plant tissues in the fossil record (Labandeira, 2007a). For example, true roots were not herbivorized until 98 million years after their initial appearance in the fossil record (Weiss, 1904; Labandeira, 2001; Slater et al., 2012); wood boring in cambial tissue is present only 62 million years after wood (secondary xylem) initially occurs 


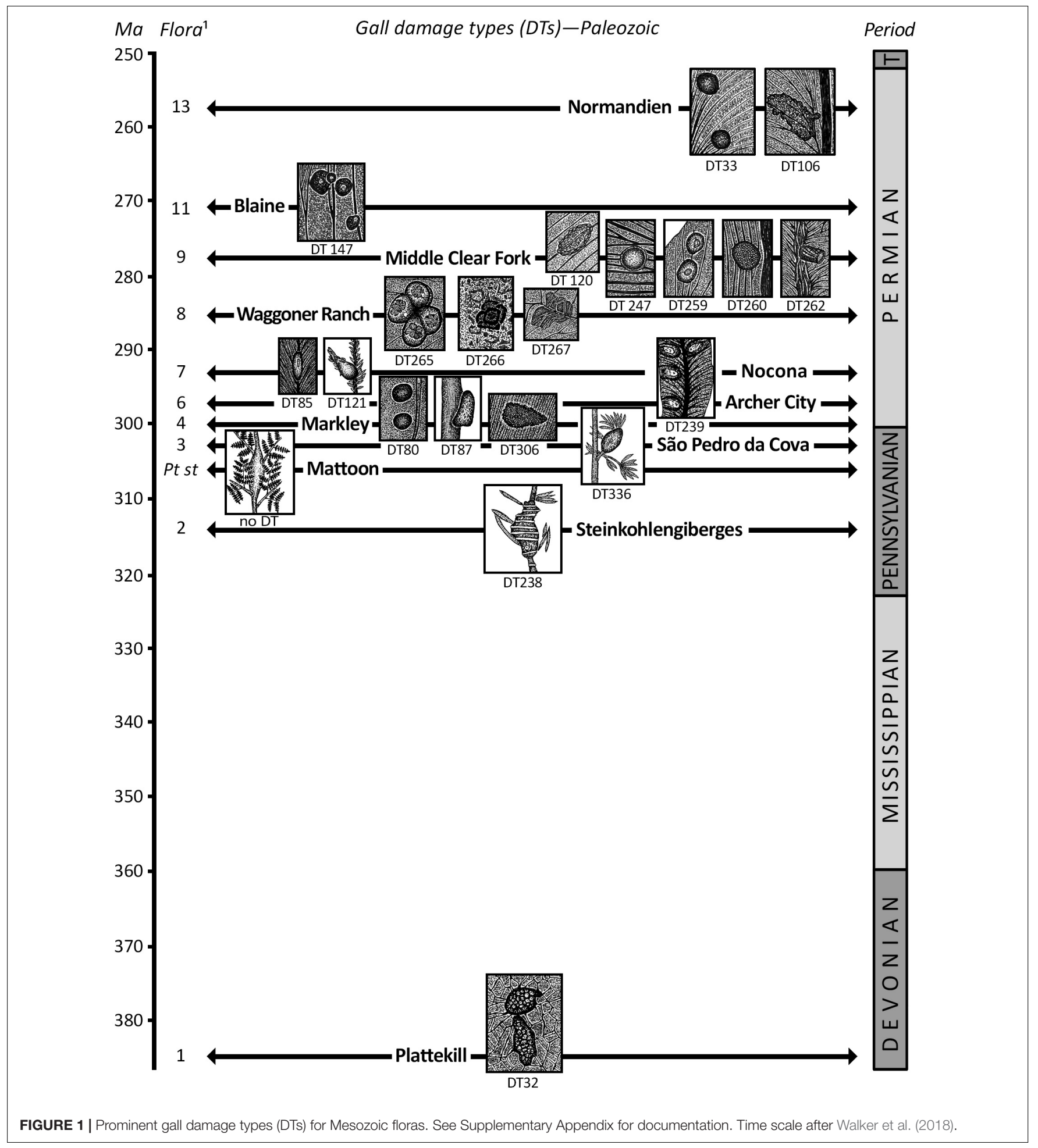

(Dunn et al., 2003); and similarly, seed predation postdates by 54 million years the first appearance of seed plants (Jennings, 1974; Scott and Taylor, 1983). However, folivory does not fit this pattern. DTs attributable to margin feeding and hole feeding by an unknown arthropod culprit appears on two lineages of seed plants twice during the Mississippian Period (Iannuzzi and Labandeira, 2008; M. Donovan, pers. commun.). These occurrences of arthropod herbivory on seed-plant leaves but absences of many other feeding guilds suggest that possibly the spectrum of folivores included not only margin feeders and hole feeders, but gallers as well. The presence of exophytic folivores during this time interval documents their colonization of seed 
plants and probably spore-bearing plants, but also endophytic gallers that currently are not reflected in the fossil record.

\section{Axial Galls on Horsetails, Ferns, and Coniferophytes (3)}

The earliest documented galls on vascular plants consist of three axial galls on pteridophytes, each of which has been assigned to an ichnotaxon. The first is Acrobulbillites problematicus (DT328), a sphenopsid axial gall occurring on the stem of the equisetalean horsetail Asterophyllites longifolius from the Early Pennsylvanian (ca. $319 \mathrm{Ma}$ ) Steinkohlengiberges deposit of Germany (Weiss, 1876; Van Amerom, 1973). This distinctive, tumescent gall with transverse ridges resembles certain malformations on modern horsetail stems (Humbert, 1945). A second gall is the conspicuous Paleogallus carpannularites (DT336) that emerges from a node along the axis of the equisetalean calamite, Annularia paisii, from the Late Pennsylvanian (ca. $302 \mathrm{Ma}$ ) of the São Pedro da Cova area in central Portugal (Correia et al., 2020). The gall is short-pedicellate, ovoidal, preserved three-dimensionally, and partly coalified, and has an outer surface of pustules arranged into elongate rows that parallel the medial axis and converge apically (Correia et al., 2020). Apparently, the culprit is a taxonomically unplaced holometabolous larva (Correia et al., 2020) that may be closely related to the producer of the next gall on a marattialean fern.

The third gall, for which there is more specimens and data, is the anatomical and three-dimensionally preserved rachis gall of Pteriditorichnos stipitopterii from the Late Pennsylvanian Mattoon Fm of Illinois, United States. (Because this gall is a three-dimensional and carbonate permineralized coal ball, it is not given a DT designation that are reserved only for flattened compression-impression fossils originally preserved in sediment.) The superb anatomical structure of this rachis gall preserves organ, tissue, and cell detail; displays exit or entry holes; has extensive hyperplasic and hypertrophic proliferations of nutritive tissue that include bite marks; and encompasses cylindrical fecal pellets present in an elongate chamber (Labandeira and Phillips, 1996, 2002). This gall is similar to some modern fern rachis galls (Kraus et al., 1993) caused by gall midges (Maia and Santos, 2011). Details of the gall and a frequency histogram of fecalpellet diameters indicate that there were three, possibly four instars of the larval inhabitant, suggesting one of the earliest occurrences of holometabolous insects in the fossil record (Labandeira, 2011).

By the middle of the early Permian at ca. $293 \mathrm{Ma}$ in Euramerica, a fourth, bud gall (DT121) was present on the axes of the early voltzialean conifer Walchia piniformis from Germany (Florin, 1945) and Texas (Labandeira and Allen, 2007). The Texas material from the Nocona Fm is well preserved and consists of a beaked gall positioned on conifer twig, with a bulbous base, smooth surface, and occasional, emergent conifer needles apically (Labandeira and Allen, 2007; Figure 1). This gall is similar to the extant cypress twig gall midge, Taxodiomyia cupressiananassa, that is hosted by bald cypress, Taxodium distichum, in the southeastern United States (Chen and Appleby, 1984), and the developing pineapple gall of Adelges abietis on Norway spruce, Picea excelsa, of Northern Europe (Plumb, 1953). Although the galls of this interval represent structurally different plant hosts-equisetalean horsetails, marattialean ferns, and walchian conifers - they are united by their presence on the stems, rachises, and twigs of vascular plants, but were replaced by different gall DTs on foliage during the early Permian (Figure 2).

\section{Expansion Onto Seed-Plant Foliage (4)}

The greatest coverage of Pennsylvanian and Permian plantinsect interactions that examines the earliest galls on leaves are the six, well-studied, Euramerican floras at several sites in north-central Texas (Labandeira, 2013a), listed below from oldest to youngest. These six floras, from latest Pennsylvanian to early middle Permian in age, document the expansion of galls on seed-plant foliage (Labandeira and Currano, 2013). The oldest is the Williamson Drive locality of the Markley Fm, which represents a swamp deposit within a regional wetland and consists of the insect galls DT33, DT34, DT80, DT87, and the mite gall DT106 that occur variously on lepidodendralean lycopsids, equisetalean sphenopsids, and callistophytalean, lyginopteridalean, and especially medullosalean seedferns (Xu et al., 2018) (Figure 2). The spectrum of gall damage shows a continuation of colonization of plant hosts such as lycopsids and sphenopsids from swamp floras of the earlier Pennsylvanian but lack the targeting of axial organs that evidently was replaced by galling of foliage and rarely roots. Notably, the presence of multiple gall DTs on a variety of seedfern species, particularly a dominant plant, the medullosalean Macroneuropteris scheuchzeri, shows the incipient galler colonization of seed plants. The Coprolite Bone Bed flora of the Nocona Fm, consists of a perennial pond within a floodplain that has the midrib pouch gall DT85 occurring on the peltaspermalean Autunia conferta (Labandeira and Allen, 2007), and the bud gall DT121 on the voltzialean conifer $W$. piniformis, mentioned in the previous section. The Taint flora of the Waggoner Ranch Fm, comprises a small basin marginal to a small watercourse (Beck and Labandeira, 1998), but lacks galls. The Colwell Creek Pond flora of the Middle Clear Fork Fm, was deposited in a coastal embayment with marine input that is rich in mite galls and has several heavily galled plant species (Schachat et al., 2014). The ten galls DT32, DT33, DT34, DT80, DT120, DT122, DT247, DT259, DT260, and DT262 occur only on seed plants, and is the most heavily galled flora of the Paleozoic (Supplementary Appendix 1). Galls occur on multiple species of the probable cycadophyte Taeniopteris spp., an indeterminate broadleaved seed plant, peltaspermaleans Sandrewia texana and Auritifolia waggoneri, possible peltaspermalean Supaia thinnfeldioides, and gigantopteridalean Evolsonia texana (Schachat et al., 2014) (Figure 2). The two dominant foliar taxa of A. waggoneri and Taeniopteris spp. are heavily galled and share 6 of the 10 gall DTs that are the most common and ordinary in the flora. The more structurally distinctive galls that have unique features tend to occur only on a single host plant, typically A. waggoneri. The Mitchell Creek Flats flora of the Waggoner Ranch Fm was deposited adjacent to a stream in a seasonally arid environment and is a moderately galled flora with DT32, 


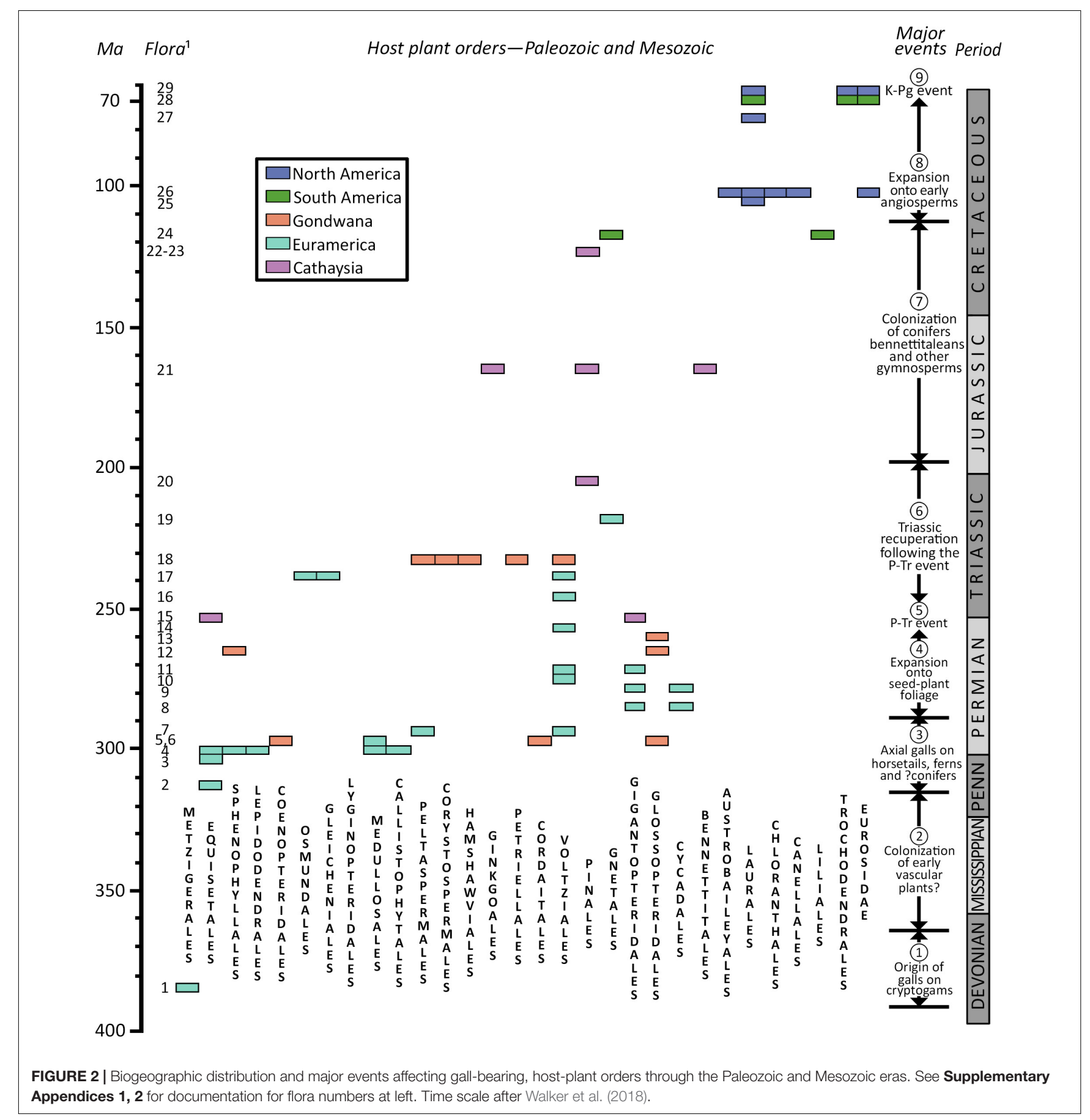

DT80, DT247, DT265, DT266, and DT267 that occur on the probable cycadophyte Taeniopteris spp., the gigantopteridalean Zeilleropteris sp., and an indeterminate broadleaved plant (Schachat et al., 2015). All galls are on seed-plant hosts, including the multiple forms of Taeniopteris spp., which probably is the same taxon at Colwell Creek Pond. The youngest South Ash Pasture flora of the Blaine Fm occurs in a seasonally dry channel within an arid regional environment and supports DT33, DT34, DT62, and DT147 on broadleaved seed plants of the gigantopteridalean Euparyphoselis gibbsoni and the voltzialean conifer Johniphyllum multinerve (Looy, 2020; Maccracken and Labandeira, 2020). These six floras represent a variety of paludal, lacustrine, and fluvial environments in essentially the same geographic area during an approximate 30-million-year-long interval. During that time, 19 gall DTs have been documented, of which 5 only occur on spore-bearing plants of the Williamson Drive flora. Notably, these gall DT assemblages exhibit little overlap among the floras, with the most common DTs of DT32, 
DT33, DT34, and DT80 having recurring occurrences. It appears that the early history of gall associations on seed-plant hosts display both generalized and specialized associations.

The only other early Permian locality with DT data is the LeFaine flora of the Tregiovo Fm of northeastern Italy (Labandeira et al., 2016a; Bernardi et al., 2017), in which the broadleaved conifer Quadrocladus was minimally galled. This flora in eastern Euramerica displays few plant-insect interactions and lies in stark contrast the more heavily galled floras from Texas in western Euramerica. In Gondwana, the South African Vereeniging Quarry flora (Plumstead, 1963), shows a distinctive gall at the base of the glossopterid leaf Palaeovittaria kurtzii (McLoughlin, 2011).

A locality of middle Permian age that is a few million years younger than the South Ash Pasture flora is the Deseado Massif flora of the La Golodrina Fm in southeastern Argentina (Cariglino, 2020; also see Adami-Rodrigues et al., 2004). This flora, rich in mite galls, contains the blister galls of DT52, an unidentified DT, the pouch gall DT85, and the three erineum galls of DT107, DT120, and DT260, all occurring on typical Gondwanan glossopteridalean seedplant hosts. A second locality, somewhat younger than the Deseado Massif flora, is the Ulan Coal Mine flora from the Illawarra Coal Measures of Australia, which displays a distinctive gall at the base of Glossopteris acutifolia leaves (McLoughlin, 2011). Because of currently sparse and idiosyncratic data, it is unclear whether particular glossopteridalean hosts display the same spectrum of DTs across the major continents of Gondwana.

Three late Permian bulk floras evaluated using the FFG-DT system, from oldest to youngest, are the Gondwanan Clouston Farm flora from the Normandien Fm of central KwaZulu-Natal, in South Africa (Prevec et al., 2009); the Euramerican Bletterbach Gorge flora from the Gröden Sandstone of the Trentino-Alto Adige region of northeastern Italy (Labandeira et al., 2016a; Bernardi et al., 2017; Kustatscher et al., 2017); and the Cathaysian Guanbachong and Taohujing floras from the Kayatou Fm of northern Yunnan Province, China (Liu et al., 2020). These three floras collectively contain the insect and mite gall DTs of DT33, DT106, DT115, DT127, and DT153, the latter three of which are cover, mark, and blister galls not found in earlier Permian floras. From Gondwana, for floras not using the FFG-DT system, there is the late Permian Stony Creek flora of the Black Alley Shale from the Bowen Basin in east-central Queensland of Australia (McLoughlin, 2011). This flora has revealed two distinctive galls on the leaves of Glossopteris xiphophylla and G. bucklandensis.

Throughout the Permian, seed-plant hosts of floras from southern hemisphere Gondwanan continents were almost exclusively dominated by the glossopteridalean hosts of Glossopteris, Gangamopteris, and related taxa (Banerjee and Bera, 1998; Adami-Rodrigues et al., 2004; Srivastava, 2007; Pinheiro et al., 2012)-a phytogeographical pattern quite different than more diverse major plant taxa from the northern hemisphere landmasses of Euramerica, Angara, and Cathaysia (Vasilenko, 2007; Liu et al., 2020). These northern continents supported medullosaleans early during the Permian, then later gigantopteridaleans, peltaspermaleans, voltzialean conifers, and a variety of cycadophytes throughout the Permian, with corystospermaleans appearing at the end of the period. It appears, at least tentatively and overall, that the diversity of galling was approximately equal among the continents of the southern and northern hemispheres during the Permian. Although the insect faunas of the Permian show very sporadic occurrences (Vishniakova, 1981; Shcherbakov, 2000; Beckemeyer, 2004), based on a size analysis and the correlation between size and galling insects (Ananthakrishnan and Raman, 1989; Schaefer et al., 2005; Raman, 2012), small hemipteroids such as Protopsyllidiidae and Lophioneuridae were the most obvious galling insects (Schachat and Labandeira, 2015). However, eriophyioid mites are another suspected culprit although they lack a Permian fossil record (Boczek and Shevchenko, 1996).

\section{Permian-Triassic Ecologic and Evolutionary Crisis (5)}

The Permian-Triassic (P-Tr) ecologic and evolutionary crisis, and associated extinction event, has been characterized as the most extensive disruption of marine and continental life recorded during the past 541 million years (Jablonski, 2002; Hochuli et al., 2010). For insects and plants on land, there was significant turnover, as evidenced by the extinction of major lineages such as the paleopterous superclade Paleodictyopteroidea (Labandeira and Sepkoski, 1993) and the seed-plant superclade Glossopteridales (McElwain and Punyasena, 2007), even though remnant but functionally extinct subclades may have persisted into the Early Triassic, known as dead clade walking (Jablonski, 2002). In a recent study of this event (Schachat and Labandeira, 2021), it appears that ecologic replacement and evolutionary turnover were major driving forces for this event, a pattern possibly following a severe reduction in the abundance and biomass of constituent clades. This hypothesis explains the pattern of plant-gall recovery during the earlier Triassic and subsequent expansion of these associations during the latter Triassic.

\section{The Mesozoic Era}

For insect and mite galls and their host plants, the Mesozoic is divided into three intervals that do not correspond with the three geological periods of Triassic, Jurassic, and Cretaceous of the Mesozoic Era. The first interval is most of the Triassic, which represents the 25-million-year-long recovery period from the P-Tr ecological and evolutionary crisis that extends to the early Late Triassic at approximately the Carnian-Norian stage boundary at $228 \mathrm{Ma}$. The second interval is the succeeding 93 million-year-long balance of the Triassic, all of the Jurassic, and the first part of the Early Cretaceous, up to the earliest occurrence of angiosperms. The third interval represents the 69-million-year-long co-association with angiosperms, up to the Cretaceous-Paleogene (K-Pg) extinction event and ecological crisis at $66 \mathrm{Ma}$ (Figure 3; Supplementary Appendix 2).

\section{Triassic Recuperation Following the Permian-Triassic Event (6)}

Very little is known about plant-insect interactions during the 5-million-year-long "dead zone" following the P-Tr ecologic and evolutionary crisis (Shcherbakov, 2008a,b). The only published 


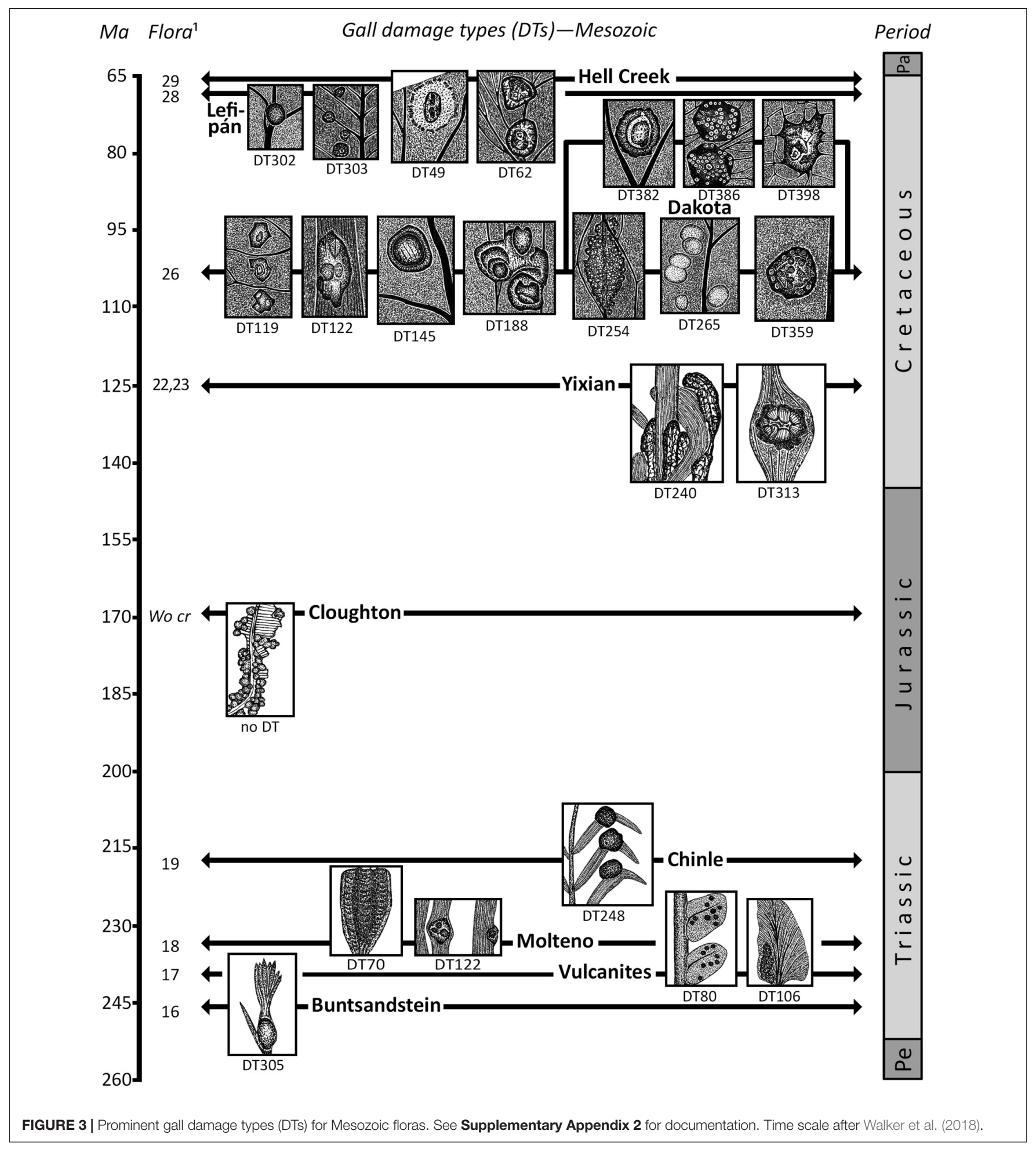

record for endophytic interactions is two gall morphotypes and a leaf mine on Vjaznikopteris rigida, a rare peltaspermalean from Russia close to the P-Tr boundary interval (Krassilov and Karasev, 2008). A second gall occurrence from the Early Triassic-Late Triassic boundary interval of the Newport Fm in the Sydney Basin of New South Wales, Australia, occurs on the pinnate leaf of the corystospermalean Dicroidium odontopteroides (McLoughlin, 2011). These unique galls have thick, prominent outer walls, a central spheroidal chamber represented by a tubercle, and intervening nutritive tissue. The gall morphology has been analogized to modern Neuroterus galls of tenthredinid Hymenoptera (Kinsey, 1922; Rosenthal and 
Koehler, 1971), although there are subtle differences in structure (McLoughlin, 2011). If the gall insect fauna that existed on late Permian glossopterid hosts was extinguished at the P-Tr event, then the presence of distinctive galls at Early Triassic-Middle Triassic boundary would indicate establishment of complex gall associations within 5 or 6 million years of the event. Nevertheless, recovery to the moderate level of plant-insect interactions, including gall associations (Kinsey, 1922), that was present during the late Permian (Labandeira et al., 2016a; Kustatscher et al., 2017; Liu et al., 2020), took approximately 15 million years. A late Permian level of diversity was not matched until the late Middle Triassic, based on evidence from Euramerican floras of northeastern Italy (Wappler et al., 2015; Labandeira et al., 2016a).

Some of the best evidence for early Middle Triassic gall associations comes from the Grès à Voltzia flora of eastern France and western Germany, where three distinctive gall associations occur on voltzialean conifers (Grauvogel-Stamm, 1978; Grauvogel-Stamm and Kelber, 1996). A distinctive gall occurs at the base of Aethophyllum stipulare, a presumptive herbaceous gymnosperm with a DT305 gall at its base that is bulbous and apparently resulted in an abortion of its pollen cone. A second stem gall occurs on a Voltzia stem that displays a lenticular expansion of stem tissue with modification of partly embedded needle leaves. A third gall occurs on a Voltzia twig that resembles a witch's broom, with tissue proliferation associated with an abnormal bend in the stem. Several floras of the early and late Middle Triassic from northeastern Italy have been described from the same regional ecosystem (Wappler et al., 2015; Labandeira et al., 2016b). The most notable of these is the Monte Agnello flora of the late Middle Triassic of the Vulcanites Fm in Trentino, Italy, which displays a broad spectrum of plant-insect interactions, particularly on the peltasperm Scytophyllum bergeri. Scytophyllum exhibits 11 plant-insect associations, including a DT80 gall, that form its herbivore component community, the most diverse of the Italian Middle Triassic. This component community contrasts with the most diverse component community of the late Permian, the Gröden Flora in the same region, that of the voltzialean conifer Pseudovoltzia liebeana. This host has one gall (DT33) but about one-third of the plant-insect interaction DTs as Triassic Scytophyllum.

The Aasvoëlberg-411 locality (Aas-411) of the Molteno Formation from the northeastern Cape Province in South Africa has several plant hosts that harbor eight gall DTs, six of which, DT32, DT33, DT55, DT87, DT123, and DT161, are of generalized or intermediate host specificity, and two of which, DT70 and DT122, are of specialized specificity (Labandeira et al., 2018). The 178 occurrences of the eight gall DTs occur on seven seed plants: the corystospermaleans Dicroidium crassinervis and D. odontopteroides, the voltzialean Heidiphyllum elongatum, the hamshawvialean Sphenobaiera schenckii, the peltaspermalean Lepidopteris stormbergensis, and unidentifiable seed-plant foliage and axes. The generalized galls are present on leaf tissues between veins (DT32), on primary leaf veins (DT33), petioles (DT55), and small twigs (DT87), whereas specialized galls occur on pinnules and adjacent rachises (DT70), or on primary veins (DT122), as curling and cupping of entire leaves (DT123), and a blister gall represented by a faintly ridged hemispherical surface (DT161). The two most galled taxa are $D$. crassinervis with 121 galls (68.0\%) and S. schenckii with 35 galls $(19.7 \%)$ that collectively represent $87.7 \%$ of all gall occurrences. Notably, of the 121 galls on $D$. crassinervis, 117 represent the monospecific association with DT70, or $65.7 \%$ of all galls, and, together with the other monospecific association of S. schenckii that represent $19.7 \%$ of all galls, amount to $85.4 \%$ of all gall associations at Aas- 411 that are attributable to these two host-specific gall associations. The data indicate that a corystospermalean was the dominant galled plant host (see below), and that a hamshawvialean, a ginkgophyte lineage, was the subdominant galled host.

Under a regime of a high level of sampling, elevated specimen numbers, and good preservation, substantial understanding of fossil gall biology can be achieved. A clear example is DT70, a distinctive, host-specialized, mite gall from the Aas-411 locality. DT70 has a host specificity index of 3 that is present on 117 of the 120 specimens of its host plant, the corystospermalean D. crassinervis; two other occurrences occur on the very closely related $D$. odontopteroides, and a single occurrence is present on the unrelated voltzialean broadleaved conifer $H$. elongatum (Labandeira et al., 2018). Of 3064 specimens of D. crassinervis examined at Aas-411, DT70 targeted 117 specimens for an attack rate of $3.82 \%$. Notably, 50 other occurrences of this monophagous gall, all on $D$. crassinervis, are present in eight other localities of the Molteno Formation that range from 1 to 6 occurrences per locality, and a ninth locality with 23 occurrences. In the five habitats among the 10 localities where the DT70 gall is presentSphenobaiera Closed Woodland, Mature Dicroidium Riparian Forest, Immature Dicroidium Riparian Forest, Heidiphyllum Thicket, and Dicroidium Open Woodland-DT70 lacks a community-level preference, indicating that the distribution of this gall is not determined by ecological setting, but rather by specificity for a particular host-plant species. DT70 has not been recorded on any plant host, $D$. crassinervis or otherwise, in coeval strata of other Gondwanan continents such as Australia, South America, and Antarctica, a consequence attributable to low sampling levels (Schachat et al., 2020).

DT70 is an erineum gall that initially became established on the epidermis along the distal aspects of the broad, flat pinnules of D. crassinervis (Labandeira et al., 2018). The gall initially appears as a slightly swollen, irregular, pustulate surface consisting of minuscule chambers that are $0.1-0.3 \mathrm{~mm}$ in diameter (Labandeira et al., 2018). The pockmarked appearing gall subsequently expanded to the entire pinnule, increasing in intumescence and surficial raggedness, particularly on the tops of the three to five major veins where it formed a rounded, elongate prominence along each vein. During the mature phase, the gall invaded epidermal tissues of the rachis between adjacent pinnules and eventually engulfed epidermal tissues of adjacent pinnules as the pustule diameter increased. Eventually, the galls became sufficiently robust that the original foliar features of the pinnules became completely obscured. The mature gall morphology indicates that a mite is the culprit and has strong parallels in the morphology of modern erineum galls caused by eriophyid mites (Von Schlechtendal, 1916; Lamb, 1952; Jeppson et al., 1975; Kiefer et al., 1982). Notably, a mite body fossil has been 
found in slightly younger Triassic amber from the Heiligkreuz Fm of the Dolomite Alps in northwestern Italy, associated with the extinct conifer lineage Cheirolepidiaceae (Sidorchuk et al., 2015). This discovery is consistent with phylogenetically based age estimates of Eriophyioidea mites originating during the late Paleozoic (Krantz and Lindquist, 1979).

Of Late Triassic age are three gall occurrences-Gondwanan, Euramerican, and Cathaysian-that exhibit distinctive morphologies. The Gondwanan gall is on the pinnules of the corystospermalean Dicroidium hughesii from the Parsora Fm of Madhya Pradesh in central India (Ghosh et al., 2015), and consists of a robust, discoid gall with a very thick outer wall and central prominent chamber, separated by a thin encircling sulcus interpreted as nutritive tissue. Of about the same age, an Euramerican gall is on the possible gnetophyte Dechelleya gormanii from the Chinle Fm of Canyon de Chelly, AZ, United States (Ash, 1997). The hemispheroidal galls occur at mid-length on leaves of a sub-oppositely pinnate leaf where they exert a significant distortion on the leaf blade, frequently causing flexure of the leaf. The Cathaysian gall occurs from the latest Triassic Yangcaogou flora from the Yangcaogou Fm of Liaoning Province in Northeastern China, on the broadleaved pinalean Podozamites-Lindleycladus species complex. The gall, DT80, occurs on PodozamitesLindleycladus leaves as a small, inconspicuous, hemispheroidal gall with a smooth surface (Ding et al., 2015), although these three single, sparse occurrences collectively exhibit a small fraction of the morphological diversity of galls described from the Molteno Fm of the earlier Late Triassic, which apparently experienced a wave of diversification (Cenci and Adami-Rodrigues, 2019).

\section{Colonization of Conifers, Bennettitaleans, and Other Gymnosperms (7)}

Although the potential is great, especially for the study of entire floras such as the latest Middle Jurassic Jiulongshan Fm in Northeastern China, no entire Jurassic flora has been systematically examined for plant-insect interactions in general or plant-gall interactions in particular (Vasilenko, 2005; Pinheiro et al., 2016). The gall record of Jurassic plants is geographically very scattered and consists of single, noteworthy occurrences or assignments of plant features (Sahni, 1948), some of which subsequently were reassigned as galls (Alvin et al., 1967; also see Stull et al., 2013, for a Paleozoic example).

A good example of such a reassignment to a gall is Wonnacottia crispa, from the Cloughton Fm, of the Yorkshire region in northeastern England, which was described as a bennettitalean microsporophyll that bore irregularly arranged pollen sacs (Harris, 1942). Upon a re-evaluation of the original material, the specimen, together with additional material, was determined to be a highly galled bennettitalean leaf of Anomozamites nilssoni that is well known in the Yorkshire flora (Alvin et al., 1967; Scott et al., 1994). Another example of a pollen organ with a probable gall is the pinalean cone, Maculostrobus rajmahalensis, which bears an inflated base with anomalous, sac-like structures that probably represent galls (Vishnu-Mittre, 1957). These bennettitalean and pinalean structures suggest that pollen-bearing reproductive organs likely may have been sites for gallers long before the appearance of angiosperms.

Of somewhat younger Middle Jurassic age is the Eurombah Fm from southern Queensland, Australia, that reveals ellipsoidal expansions at the tips of the pinalean Elatocladus sp. (McLoughlin et al., 2015). From the Yanliao Flora of the latest Middle Jurassic Jiulongshan Fm in Inner Mongolia is the pinalean Podozamites lanceolatus-Lindleycladus lanceolatus species complex that was substantially galled. This broadleaved conifer exhibits the four galls of DT33 and DT34, which are pit, mark, or blister galls; DT116, an armored scale gall, similar to extant representatives (Miller and Davidson, 2005); and DT161, a blister gall (Ding et al., 2015). The distribution of these galls on the Podozamites-Lindleycladus species complex may represent intensification of galling during the later Jurassic.

From the mid-Late Jurassic Purlawaugh Fm of New South Wales, Australia, an obovate gall with curvilinear striae was figured on the pinalean host Rissikia talbragarensis (McLoughlin et al., 2015). The younger Chernovskie Kopi locality of the latest Jurassic to earliest Cretaceous boundary interval of Transbaikalia, Russia, has produced two taxa of gymnospermous plants that display galls using standard ichnological taxonomy (Vasilenko, 2005). The two galls are considered ichnospecies of the ichnogenus Paleogallus within the ichnofamily Paleogallidae. The pinalean host Desmiophyllum sp. possesses galls of Paleogallus zherichini that are canker-like, polylobate disruptions of leaf tissue with considerable internally disrupted tissue and thin, unhardened gall walls. From the same locality, the ginkgoalean host Ginkgoites sp., commonly present in Jurassic floras worldwide, supports Paleogallus porusoformis that consists of small, hemispheroidal, undistinguished galls with smooth surfaces, and encircling walls that appear similar to DT80.

\section{Expansion Onto Early Angiosperm Lineages (8)}

The major event during the Cretaceous Period for gall biology was the evolutionary expansion of angiosperms in a variety of ecosystems during the 30-million-year-long interval from 125 to $90 \mathrm{Ma}$ of the mid-Cretaceous, during which there was a major transformation of floras from gymnosperm dominance to angiosperm dominance (Labandeira, 2014; Peris et al., 2020). For gymnosperm-dominated floras of the earlier Cretaceous, some of which partly overlap with the gymnospermto-angiosperm transitional interval, the Jehol Flora of the mid-Early Cretaceous Yixian Fm from three localities in Inner Mongolia and Liaoning reveals that the plant laden with the most plant-insect interactions as well as galls was the dominant broadleaved pinalean Liaoningocladus boii (Ding et al., 2015). This host represents the youngest slice of time from a time-series study (Ding et al., 2015) of broadleaved pinalean conifers through the three slices of Late Triassic for Podozamites-Lindleycladus (Yangcaogou flora), Middle Jurassic for Podozamites-Lindleycladus (Yanliao flora), and Early Cretaceous for Liaoningocladus (Jehol flora) of Northeastern China. This study revealed an increase in galling diversity through this approximately 75-million-year-long time interval (Ding et al., 2015). Broadleaved conifer taxa in the late Triassic Yangcaogou flora exhibited one gall (DT80), those of the 
Middle Jurassic Yanliao flora displayed four galls (DT33, DT34, DT116, and DT161), and L. boii of the Jehol flora supported five galls (DT80, DT122, DT127, DT240, and DT280), with a shift to more specialized galls. In addition, tentative evidence indicates substantial provinciality in gall distribution among the several contemporaneous floras of the Yixian Fm; whereas gall DT240 only occurred at the Dawangzhangzi locality, gall DT313 was present only at the Huangbanjigou locality (Wong et al., 2015). This latter gall resembles closely a tenthredinid gall (Clancy et al., 1986; Berry, 1997; Charles and Allan, 2000).

An approximately 7-million-year-younger flora is the Crato flora from the mid-Early Cretaceous Crato Fm of southern Cearà State in Brazil. Three noteworthy associations of plantgall associations have been determined for this flora (Filho et al., 2017). They are DT32, a pit, mark, or blister gall on the lilialean monocot Cratomilax jacksoni, DT116, an armored scale gall on the aquatic angiosperm Klitchophyllites flabellatus, and DT117, a pouch gall on an unaffiliated gnetalean (Filho et al., 2017). The presence of two galls on angiosperms in a wet or humid environment may have been a prelude to the broad diversity of galls in the 15-million-year-younger Dakota flora, representing an early period of diversification (Cook and Gullan, 2004).

A phenomenal expansion of plant-insect interactions occurred during the initial expansion of angiosperms, as evidenced by the Rose Creek locality of the latest Early Cretaceous (103 Ma) Dakota Fm of Nebraska, United States, and the 11-million-year-younger Gerofit flora of Israel. At the Rose Creek locality, 114 specific interactions (DTs) representing the 11 FFGs of hole feeding, margin feeding, skeletonization, surface feeding, oviposition, piercing and sucking, mining, galling, seed predation, borings, and pathogens were present (Xiao and Labandeira, 2020: personal observation) on early-appearing, basal lineages of Austrobaileyales, Chloranthales, Laurales, Canellales, and Eurosidae (Upchurch and Dilcher, 1990). For the galling FFG, 24 galls are present that represent a wide variety of gall DTs, gall groups, host specificities, plant hosts, and modern arthropod gall analogs (Xiao and Labandeira, 2020: personal observation; Supplementary Appendix 2). The gall DT data can be partitioned based on host specificity. Galls with generalized host specificities represent $40 \%$ of all galls, including DT80, DT106, DT117, DT122, DT145, DT247, DT254, DT289, DT303, and DT359 galls, and consist of pit, erineum, pouch, cover, spangle, and blister gall groups. Galls with an intermediate level of host specificity represent $28 \%$ of all galls, including DT85, DT87, DT119, DT194, DT266, DT386, and DT398 galls, and consist of the pouch, cover, spangle, and blister gall groups. Galls with specialized host specificities represented 32\% of all galls, including DT34, DT52, DT120, DT153, DT188, DT189, DT205, and DT265 galls, and consist of pit, mark, or blister; erineum; spangle; cover; and blister gall groups. There appears to be no relationship between host specificity, DT, and gall group, nor is there any correspondence to plant host (Supplementary Appendix 2). One notable aspect of Rose Creek plant-insect interactions is that whereas $32 \%$ of gall DTs were host specialists, none of the 20 mining DTs were specialists. This difference in host specificity indicates that among early angiosperm floras, galler insects were partitioning plant taxa in a substantially more intensive way than mining insects (Xiao and Labandeira, 2020: personal observation).

Another, diverse gall fauna is represented in the early Late Cretaceous (92 Ma) Gerofit flora from the Ora Fm along the Arava Rift Valley of the southern Negev region in Israel (Krassilov, 2007, 2008; Krassilov et al., 2008). Eight dicot and two monocot angiosperms whose taxonomic affinities are poorly understood are hosts of the 69 interactions. The authors do not use the DT-FFG system, but rather introduce a novel ichnotaxonomic classification to describe new types of oviposition, piercing and sucking, mining and galling, leaf larval cases, and external insect or fungal damage to the mines and galls. (See Vasilenko and Maslova (2015) for a critique of this approach.) The 25 new galls that are described are based on a broad definition of galls that consists of abnormal differentiation of plant structures induced by another organism, including proliferations of tissue induced by oviposition. Four categories of galls and 10 ichnogenera (see Ross, 1932) were described for fossil galls of the Gerofit flora (Krassilov et al., 2008). Procecidimorpha consist of callus and other reaction tissue with hyperplasia that surrounds oviposition scars consisting of an incipient gall-like structure (Redfern, 2011). Procecidimorpha historically have not been considered as true galls (Meyer, 1987). Procecidimorpha galls are represented by six ichnospecies assigned the ichnogenera Cupuleon and Foveon (Krassilov et al., 2008). Catacecidimorpha, or cataplasmic galls, are a type of histoid gall characterized by a minor deviation from the normal growth pattern of its host, consisting of multiple layers of parenchymatous cells and lacking a definitive morphology (Meyer, 1987; Rohfritsch, 1992). Catacecidimorpha galls are represented by 11 ichnospecies assigned to the ichnogenera Emergeon, Pustuleon, and Lenticeon (Krassilov et al., 2008; Krassilov and Shuklina, 2008). Prosocecidimorpha are prosoplasmic galls, a type of histoid gall defined by better organized, induced tissue with differentiation, for example, into vascular, nutritive and sclerenchymatous tissue to attain multiple gall functions whose morphology is specific to its host plant (Meyer, 1987; Rohfritsch, 1992). Prosocecidimorpha galls are represented by four ichnospecies assigned to the ichnogenera Cephaloneon and Ceratoneon (Krassilov et al., 2008). Organocecidimorpha are organoid galls typified by a modifications of active regeneration tissues, such as meristems, and cause malformations of organs, such as witch's brooms for vegetative organs or conifer cone galls for reproductive organs (Bronner, 1992; Rohfritsch, 1992). Organocecidimorpha are represented by nine ichnospecies assigned to the ichnogenera Petioleon, Costaeon, and Involuteon. The 25 galls described in the Gerofit flora and the approximately 11-million-year-older Rose Creek flora appear to be of about the same morphological richness, suggesting that the broad spectrum of galling relationships was established early within the diversification of angiosperms. However, the Gerofit galls display a substantial amount of parasitoid predation, particularly in the form of small exit holes on gall surfaces, which were very rare at the Rose Creek locality (Krassilov, 2008), suggesting an increase in top-to-down trophic regulation of insect herbivore guilds (Labandeira and Li, 2021). For a modern example, see Joseph et al. (2011). 
Galls have been documented throughout the Late Cretaceous of Europe and North America as single occurrences (Stephenson, 1991; Scott et al., 1992) rather than systematic studies by intense sampling of entire, diverse, abundant, and well-preserved floras. Nevertheless, very little is known about arthropod galls on plants of later Late Cretaceous Floras. One plant species that has been intensively investigated for its galls is the lauralean Catula gettyi from the Late Cretaceous Kaiparowits Fm of southern Utah, United States, which registered the host-generalized galls of DT32, DT33, and DT34, and the specialized gall DT85. Another highly sampled angiosperm host also bore the earliest occurrence of a lyonetiid moth mine (Maccracken et al., 2021).

\section{Cretaceous-Paleogene Ecologic and Evolutionary Crisis (9)}

The Cretaceous-Paleogene (K-Pg) extinction event and associated ecologic and evolutionary crisis was second only to the P-Tr event as the most perilous period to affect the fate of continental life during the past 450 or so million years. In addition to the annihilation of non-avian (and avian) dinosaurs, pterosaurs, crocodyliforms, and freshwater bivalves (Labandeira et al., 2016b), the bolide impact also had a substantial effect on plant-insect interactions (Labandeira et al., 2002a,b). Notably, while insects at the family level suffered no extinction beyond background levels during this time interval (Labandeira and Sepkoski, 1993), land plant taxa experienced a significant decline at the boundary (McElwain and Punyasena, 2007). Data from the K-Pg boundary spanning the Hell Creek Fm (latest Cretaceous) to Fort Union Fm (earliest Paleogene) formational boundary, representing 2.2 million years (1.4 million years Cretaceous; 0.8 million years Paleogene) from the Williston Basin of North Dakota, United States, was examined for the effect on plant-insect interactions. That effect, as recorded by 51 DTs representing the eight FFGs of hole feeding, margin feeding, skeletonization, surface feeding, galling, mining, piercing and sucking, and oviposition indicates a minimal effect on generalized associations, an in-between effect for associations with intermediate host specificity, and a drastic effect on host-specialist associations (Labandeira et al., 2002b). Of the 20 specialized DTs that were dominated by piercing and sucking, mining, and galling, only four successfully survived into the earliest Paleogene. For the specialized gall associations of DT33, DT49, DT52, DT55, and DT62, only one, DT33, statistically survived into the Paleogene. The two generalist gall associations, DT32 and DT34, were statistical survivors. This suggests that the effect of the K-Pg event did not extinguish the galling habit so much as it wiped out the habit of host specialization.

A similar study was conducted in the southern hemisphere to examine the effect of the K-Pg extinction event on plantinsect actions from four stratigraphic levels that span about 5 million years along the boundary in Chubut Province, central Patagonia, Argentina (Donovan et al., 2016, 2018). Sixty-nine DTs from the hole feeding, margin feeding, skeletonization, surface feeding, piercing and sucking, oviposition, mining, and galling FFGs were evaluated from the latest Cretaceous Lefipán Fm, and earliest Paleogene Salamanca Fm consisting of the
Palacios de los Loros 1 locality (lower strata), Palacios de los Loros 2 locality (upper strata), and the uppermost Peñas Coloradas Fm. Of the total associations, 26.1\% were specialized and $73.9 \%$ were generalized. Of the eight specialized gall associations present in the Lefipán Fm of Patagonia, three (37.5\%) did not survive into the Paleogene, a much lower percentage than that of the Williston Basin. A comparison of these two values-one from the northern hemisphere and another from the southern hemisphere-indicates that for plant-gall insect associations, the effect of the K-Pg ecological and evolutionary crisis was considerably lessened for gall associations south of the paleoequator (Donovan et al., 2016, 2018).

\section{The Cenozoic Era}

The Cenozoic Era, because of its recency relative to the Paleozoic and Mesozoic, is the time interval that is best documented for plant-insect interactions in general and gall interactions in particular. Unlike earlier biologic events, such as the expansion of seed plants during the Permian Period, the ecologic rebound during the Triassic following the $\mathrm{P}-\mathrm{Tr}$ event, and angiosperm diversification, the Cenozoic is dominated by major environmental shifts. These environmental shifts prominently are the Paleocene-Eocene Thermal Maximum (PETM), Early Eocene Climatic Optimum (EECO), global aridification commencing in the late Paleocene and continuing throughout most of the Neogene, and, finally, hothouseicehouse cycles associated with Pleistocene glaciation (Figure 4; Supplementary Appendix 3).

\section{Initial Recovery From the Cretaceous-Paleogene Event (10)}

Studies at the Williston Basin in North Dakota of the effect that the K-Pg event had within the first 0.8 million years of the Paleogene Period provide considerable data. However, this event has been supplemented by younger, early Paleogene localities from the Western Interior of North America that extend to about 6 million years after the event. These studies indicate that the effect of the K-Pg event had variable effects biogeographically, ecologically, and temporally, depending on the FFG, throughout the 6-million-year-long interval after the K-Pg boundary. The only post-event data, however, pertain to the recovery or lack thereof of mining and not galling insects for the North Dakota and Western Interior region of North America (Labandeira et al., 2002a,b; Wilf et al., 2006; Donovan et al., 2014). Nevertheless, the patterns observed for the response of mining insects to the K-Pg event might be instructive for understanding how galling insects also may have reacted during this time interval. Whereas elevated mining diversity tracks moist, humid environments, reaching a peak in the mid and lower canopy levels of subtropical and tropical forests (Connor and Taverner, 1994; Sinclair and Hughes, 2008), gallers reach a peak in mid-latitude semiarid environments at the tops of mesic subtropical and tropical canopies where they are exposed to high solar radiation and water stress (Carneiro et al., 2005; Ribeiro et al., 2014) that mimic the conditions at mid-latitude xeric environments (Fernandes and Price, 1992; Espírito-Santo and Fernandes, 2007; but see Bairstow et al., 2010). This suggests 


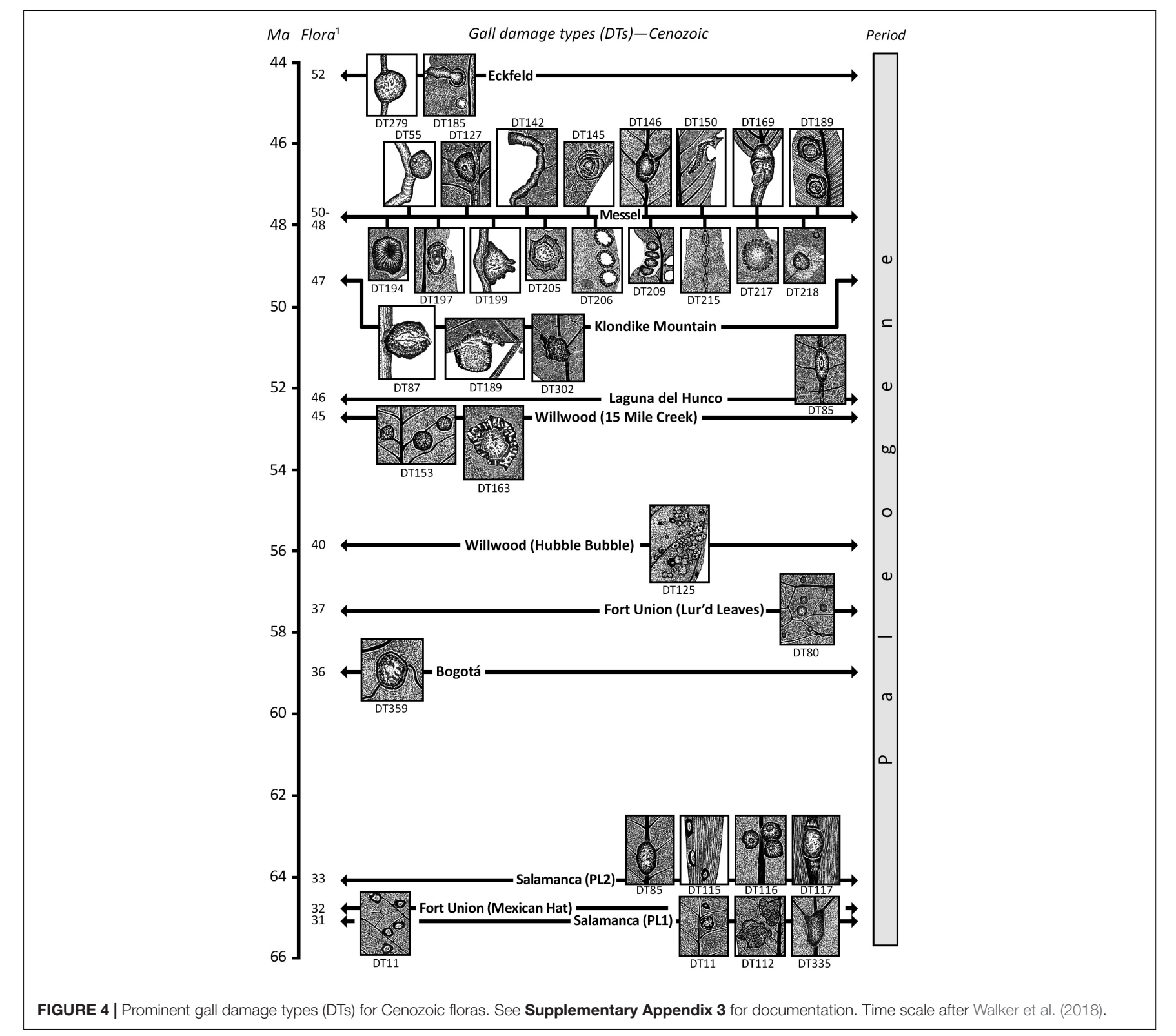

that galling insects may have had an opposite pattern than that of leaf-mining insects for the post-event short term of 6 million years.

In the southern hemisphere, the same study in Patagonia, Argentina, that tracked the fate of plant-insect associations during the same 6-million-year-long time interval following the K-Pg event (Donovan et al., 2016, 2018) provides a surprising record of insect gall survival (Supplementary Appendix 3). The mostly specialized, latest Cretaceous Lefipán galls-DT11, a blister gall on a malvalean host; DT32, a pit, mark, or blister gall on a possible vitalean host; DT33, another pit, mark, or blister gall on the same possible vitalean host; DT34, another pit, mark, or blister gall on a fagalean host; DT62, an erineum gall on multiple unknown hosts; and DT85, a pouch gall on possible vitalean and unaffiliated hosts-survived approximately from 1 to 4 million years after the event into the Palacio de los Loros 1 and 2 and the Las Flores floras. This pattern suggests a more ameliorated effect of the K-Pg event on southern hemisphere gall associations in the geochronological short term.

The post event pattern of the Menat Fm, deposited 5.5 million years after the K-Pg event, at Gannat, France (Wappler et al., 2009), provides rich data from a locality, like the Patagonian localities, that was distant from the bolide impact site at Yucatan, Mexico. The Menat locality reveals that, in addition to other FFGs, 10 gall DTs represented a variety of host specialization values, gall groups, and plant hosts, resulted in a high level of gall diversity compared to the depauperate levels during the time interval immediately after the K-Pg event documented from the Williston Basin of North Dakota (Labandeira et al., 2002a; Wilf et al., 2006). These data indicate that at the end 
of the 6-million-year long interval, recovery of gall and other associations had produced balanced food webs (Wappler et al., 2009) that were substantially different from the unbalanced food webs immediately following the K-Pg event (Wilf et al., 2006).

\section{Delayed Recovery From the Cretaceous-Paleogene Event (11)}

The longer-term effects of the K-Pg event extended from about 6 to 10 million years and represent an approximate complete recovery in plant-insect associations by the end of the time interval, the PETM (at $56.0 \mathrm{Ma}$ ). One particularly notable occurrence from this time interval are distinctive galls on leaves of the sapindalean Eomangiferophyllum damalgiriensis, a distant relative of mango, discovered in the Tura Fm of the West Garo Hills of Meghalaya State, India (Mehotra et al., 1998; Srivastava et al., 2000). The galls are very similar to modern galls of the cecidomyiid Amradiplosis echinogalliperda on modern mango, Mangifera indica (Mani, 1992), possibly indicating a long-term association (Harris, 1994) and subsequent diversification cecidomyiid gallers on leaves of this host-plant genus (Raman, 2007). Also, from this time interval is a second occurrence, the distinctive columnar gall, Antronoides krassilovi, on the protealean or saxifragalean Platimeliphyllum snatolense, from the Napana Fm from the western Kamchatka Peninsula, Russia (Vasilenko and Maslova, 2015). Because of its occurrence during the early Paleogene Period, attribution to a culprit galler is more likely to be a gall mite of the Eriophyidae (Jeppson et al., 1975; Briones, 1976), rather than a gallwasp of the Cynipidae (Russo, 2006), although limited evidence suggests an origin deep in the Cretaceous (Ronquist and Liljeblad, 2001; Ronquist et al., 2015). Taxa in both gall-inducing groups produce very similar columnar galls.

A 58-million-year-old flora from the Cerrejón Fm from La Guarjira Province of northernmost Colombia represents a very early record of a Neotropical rainforest (Wing et al., 2009; also see Carvalho et al., 2021; Giraldo et al., 2021). However, although the rate of herbivory of well-preserved leaves was high, at $50 \%$, the richness of DTs among all FFGs in both bulk samples and on individual leaf specimens show rather low levels. Most of the damage is made by external foliage feeders, and specialized damage of mining and galling is rare (Wing et al., 2009). This pattern indicates that, although early Neotropical rainforests had high herbivore pressure, the incidence of host-specialist associations from mining and galling was unusually low. However, the Bogotá flora from central Colombia, approximately 1 million years younger than the Cerrejón flora, displays much greater mining and galling associations and has the highest number of miner and galling DTs than any flora of comparable age in North America (Giraldo et al., 2021).

\section{Effect of the Paleocene-Eocene Thermal Maximum (12)}

Although a geochronological instant in time, the 120,000year interval of the PETM at $55.8 \mathrm{Ma}$ had a major effect on insect herbivores, including gall-inducing insects, and the food webs they occupied (Wilf, 2008). The Paleocene-Eocene Thermal Maximum (PETM) is a transient worldwide spike in globally elevated land surface temperatures by $5-7^{\circ} \mathrm{C}$ and an approximate tripling to quadrupling of atmospheric $p \mathrm{CO}^{2}$ (Röhl et al., 2000; Zachos et al., 2003), signaling the most intense episode in climate change during the past 66 million years of the Cenozoic (Wilf and Labandeira, 1999; Currano et al., 2008, 2010). This brief event is superimposed on a gradual warming interval from 60 to 51 million years ago that was interrupted by a short-lived cooling event at about $53 \mathrm{Ma}$, the Early Eocene Climatic Optimum (EECO) (Payros et al., 2015).

Nine, well-dated floras from the Bighorn Basin of Wyoming, United States, were examined during the interval from 59 to 52.7 million years that record 71 total DTs on dicot angiosperm leaves (Supplementary Appendix 3). Four localities, including Lur'd Leaves (P2), Dead Platypus (P3), and Daiye Spa (P4), were sampled before the PETM; the single PETM locality of Hubble Bubble (E1) was sampled; and four localities, including Cool Period (E3), PN (E4), and EECO Fifteenmile Creek (E5), were sampled after the PETM (Currano et al., 2008, 2010). The data indicate the close tracking of insect herbivore richness, as indicated by elevated DT richness, with increased temperature through this interval. For galls, the four greatest relative abundances were on plant taxa from the P3 and P4 localities preceding the PETM and the youngest EECO locality (E5) long after the PETM; the PETM E1 localities registered minor or intermediate levels of gall relative abundance (Currano et al., 2008, 2010). This pattern indicates that gall insects were predominantly hosted by non-PETM plants, a pattern largely opposite to that of external foliage feeding insects of hole feeders, margin feeders, skeletonizers, and surface feeders, and by piercers and suckers that were preferentially herbivorizing PETM plants.

In a separate area of south-central Wyoming, the Hanna Basin, a second series of pre-PETM, PETM, and post-PETM localities were examined for plant diversity, insect damage (DT) richness, and overall ecosystem structure (Schmidt et al., 2019). The results of this study indicate that plant diversity was greatest in prePETM floras but do not rebound to these values in younger PETM and post-PETM floras. By contrast, damage richness was greatest in those sites with low plant diversity and increased their richness in post-PETM floras. These data include five gall DTs (Appendix 3) and suggest that herbivore communities respond more easily to plant community structure than to plant species diversity in those communities (Schmidt et al., 2019).

\section{Response to the Early Eocene Climatic Optimum (13)}

A study of six localities from the central Rocky Mountain region examined plant hosts and their plant-insect interactions in three time slices that spanned a 13-million-year-long interval during the mid-Paleogene Period at a time of increased endemism (Currano et al., 2019). The time slices consisted of late Paleocene, immediately pre-PETM floras at $56 \mathrm{Ma}$ that represented humid-warm temperate and subtropical but primarily deciduous taxa; early Eocene EECO floras at $53 \mathrm{Ma}$ that consisted of humid-subtropical, mixed deciduous and evergreen taxa; and middle Eocene post-EECO floras at $43 \mathrm{Ma}$ that were seasonally dry, subtropical, mixed deciduous, and rich in sclerophyllous evergreens (Wilf et al., 2005). This study 
documented the response of insect herbivores to a regional climate change as reflected by the leaf physiognomy, although other intervals of the fossil record indicate there may be exceptions (Leckey and Smith, 2017). Analyses of gall DT damage through this interval indicate that (i) there was an increase in gall DTs; (ii) there was a general increase in the number of leaves with gall damage; (iii) there was a major increase in the number of host-plant species that were galled; and (iv) there was an increase in the damage ratio, equivalent to the number of gall DTs on each host species divided by the number of host species. A parallel analysis for mine DT damage showed the opposite trend. From these gall and mine data, it was concluded that insect herbivory frequency, as reflected in galling and mining patterns, was highest at the end of this interval, indicating the presence of two herbivory syndromes: one for chemically and physically poorly defended, palatable, deciduous foliage typical of the EECO early Eocene, and another syndrome consisting of plants with palatable, deciduous foliage accommodating to herbivores and heavily defended hosts with evergreen, sclerophyllous, small leaves that resisted herbivory. Leaf galling, negatively associated with moist humid habitats, increased toward the middle Eocene whereas leaf mining decreased. A third herbivory syndrome, representing a hyperherbivorized, highly accommodationist syndrome, may also have existed (Labandeira, 2007b). Several localities of the Laguna del Hunco Fm (52.2) of Chubut, Argentina, were also deposited under EECO conditions (Wilf et al., 2005), but would require further analyses to examine the effect of global cooling in the southern hemisphere at this time.

\section{Origin of Many Modern Gall Associations (14)}

The latter Paleogene Period, from 49 to $40 \mathrm{Ma}$, was a time when many distinctive, modern gall associations, or possibly their indistinguishable convergent galls, make their earliest appearances as fossils (Brooks, 1955; Moran, 1989). The oldest of the major gall-bearing floras from the mid-Paleogene deposit with several but nonetheless a wide variety of gall morphotypes is the Republic quarries, especially Boot Hill, from the Klondike Mountain Fm of Ferry County, WA, United States. Although the gall descriptions predate the use of the DT-FFG system (Labandeira et al., 2007), DT assignments retrospectively have been given to the original descriptions of Labandeira (2002). Three of the more impressive gall DTs are illustrated in Figure 4, and the spectrum of plant hosts is quite different from those of Messel, indicating a taxonomically different regional flora with assignments to Cornales, Ericales, Malvales, Rosales, and Sapindales and an associated specialized gall fauna (Labandeira, 2002) (Figure 5).

The Messel oil shale deposit, from the mid-Paleogene (47.8 Ma) Messel Fm in Darmstadt, from Hesse, Germany, provides the single most extensive documentation of these earliest occurring modern galls (Figure 4 and Table 2, Supplementary Appendix 3) and has been documented in the plant-insect associational literature since the late 1980s when the Messel deposit received widespread paleontologic attention (Labandeira et al., 2007; Wappler and Ben-Dov, 2008; Wappler et al., 2010, 2012; Dunne et al., 2014; Labandeira and Dunne, 2014). The 36 gall DTs from Messel (Wappler et al., 2010, 2012; Dunne et al., 2014; Labandeira and Dunne, 2014) are listed in Supplementary Appendix 3, of which 17 (47.2\%) of the more notable DTs are illustrated in Figure 4. Planthost specificities are $41.7 \%$ generalized, $11.1 \%$ of intermediate specificity, and $47.2 \%$ specialized. These gall DTs represent eight major gall groups of blister, cover, erineum, mark, pit, pouch, roll, spangle, and unassigned pit, mark, or blister galls. Inferred Messel culprits, based on gall morphology, planthost identifications, and food-web links (Labandeira et al., 2007; Labandeira and Dunne, 2014), consist of Acari with Eriophyidae (DT11, DT62, DT106, DT117, DT120, DT147, DT149, and DT150); Hemiptera with Aphididae (DT32, DT146, and DT169), Phylloxeridae (DT119 and DT147), and Psyllidae (DT49 and DT205); Coleoptera with Buprestidae (DT302 and DT335); Diptera with Cecidomyiidae (DT11, DT32, DT33, DT34, DT49, DT80, DT83, DT142, DT145, DT163, DT169,

TABLE 2 | Fossil damage types (DTs) and their modern analogs, with plant-host data, from the Eocene Messel Formation (47.8 Ma) of Germany.

\begin{tabular}{|c|c|c|c|c|c|}
\hline Damage type & Gall form & Fossil plant host & Modern gall analog & $\begin{array}{l}\text { Modern analog plant } \\
\text { host }\end{array}$ & References \\
\hline DT142 & Fold & $\begin{array}{l}\text { Laurophyllum } \\
\text { lanigeroides (Lauraceae) }\end{array}$ & $\begin{array}{l}\text { Macrodiplosis erubescens (Diptera: } \\
\text { Cecidomyiidae) Oak Marginal Leaf Roll } \\
\text { Gall }\end{array}$ & $\begin{array}{l}\text { Quercus ?nigra } \\
\text { (Fagaceae) }\end{array}$ & $\begin{array}{l}\text { Wappler et al., 2012; Kim } \\
\text { et al., } 2014\end{array}$ \\
\hline DT169 & Covering (petiole) & Ficus sp. (Moraceae) & $\begin{array}{l}\text { Pemphigus populitransversus } \\
\text { (Hemiptera: Pemphigidae) Cottonwood } \\
\text { Petiole Gall }\end{array}$ & $\begin{array}{l}\text { Populus deltoides } \\
\text { (Salicaceae) }\end{array}$ & $\begin{array}{l}\text { Jones, 1918; Bird et al., } \\
\text { 1979; Aoki and Moran, } \\
\text { 1994; Wappler et al., } 2012\end{array}$ \\
\hline DT199 & Covering (stem) & Unknown dicot & $\begin{array}{l}\text { Geocrypta rostriformis (Diptera: } \\
\text { Cecidomyiidae) a bedstraw gall }{ }^{1}\end{array}$ & $\begin{array}{l}\text { Galium verum } \\
\text { (Rubiaceae) }\end{array}$ & $\begin{array}{l}\text { Rohfritsch, 1987; Fedotova, } \\
\text { 1997; Wappler et al., } 2012\end{array}$ \\
\hline DT205 & Spangle & $\begin{array}{l}\text { Laurophyllum } \\
\text { lanigeroides }\end{array}$ & $\begin{array}{l}\text { Pachypsylla celtidisvesicola (Hemiptera: } \\
\text { Psyllidae) Hackberry Spangle Gall }\end{array}$ & $\begin{array}{l}\text { Celtis occidentalis } \\
\text { (Ulmaceae) }\end{array}$ & $\begin{array}{c}\text { Wells, 1916; Yang and } \\
\text { Mitter, 1993; Wappler et al., } \\
2012\end{array}$ \\
\hline DT209 & Covering (leaf) & Vitaceae sp. & $\begin{array}{l}\text { Euura proxima (Hymenoptera: } \\
\text { Tenthridinidae) Willow Bean Gall }\end{array}$ & Salix spp. Salicaceae) & $\begin{array}{l}\text { Carleton, 1938; Meyer, } \\
\text { 1987; Price, 2003; Wappler } \\
\text { et al., } 2012\end{array}$ \\
\hline DT283 & Pouch & Unknown dicot & $\begin{array}{l}\text { Aceria parulmi (Trombidiformes: } \\
\text { Eriophyidae) Elm Finger Gall }\end{array}$ & $\begin{array}{l}\text { Ulmus americana } \\
\text { (Ulmaceae) }\end{array}$ & $\begin{array}{l}\text { Wong et al., 1977; Lauriault } \\
\text { et al., 2004; Wappler et al., } \\
2012\end{array}$ \\
\hline
\end{tabular}

1. A common name is not available for this gall. 
DT206, DT215, DT217, and DT218) and Tephritidae (DT117); and Hymenoptera with Agaonidae (DT204), Chalcididae (DT32 and DT33), Cynipidae (DT145, DT163, DT186, and DT188), Eulophidae (DT84), and Tenthredinidae (DT85, DT146, DT189, DT194, DT197, and DT209) (Figure 4, Supplementary Appendix 3). Messel plant hosts are the 20 dicot angiosperm orders of Aquafoliales, Arecales, Austrobaileyales,
Buxales, Chloranthales, Ericales, Fabales, Fagales, Gentianales, Laurales, Magnoliales, Malpighiales, Malvales, Myricales, Myrtales, Nymphaeales, Poales, Rosales, Sapindales, and Vitales, and unaffiliated taxa (Figures 4, 5, Supplementary Appendix 3). The Messel flora represents the highest number of gall DTs, the highest level of plant-host specificity, and the greatest number of gall groups, galler families, and plant-host

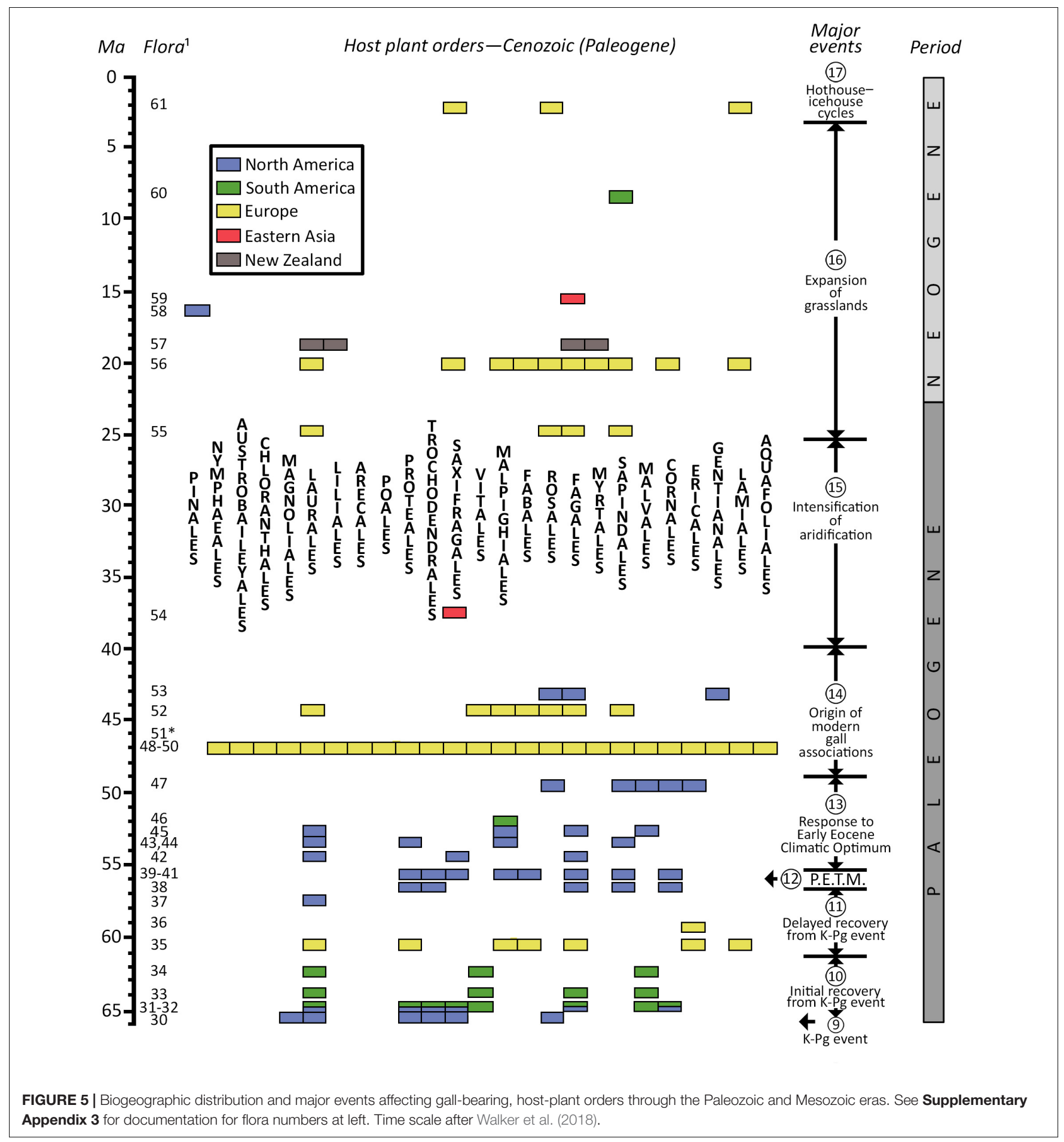


orders in the gall fossil record. In decreasing order, the most abundant gallers are Cecidomyiidae (15 attributions), Eriophyidae (eight), and Tenthredinidae (six). Plant hosts with the most galled specimens are Laurales (42 occurrences), Fagales (32), and unaffiliated taxa (28). Table 2 provides additional detail: the biologies of six notable Messel galls and their modern analogs.

The third major and youngest of the gall-bearing deposits that contain galls remarkably similar to extant plant-gall interactions are Eckfeld, a similar deposit that is 3.5 million years younger than Messel, from the mid-Paleogene Eckfeld Fm near Manderscheid, Rhineland-Palatinate, Germany. Eckfeld has received less attention than Messel, attributable to its more recent discovery, but does have 20 gall DTs that exhibit a wide variety of morphologies (Wappler et al., 2012; Figure 4, Supplementary Appendix 3), many of which overlap with DTs at Messel but may have different life habits. Plant-host specificities of Eckfeld insects are generalized (55\%), intermediate specificity (15\%), and specialized (30\%). The eight gall groups present at Eckfeld are blister; cover; erineum; pit; pouch; roll; spangle; and pit; mark; or blister undifferentiated. Insect culprits attributed to causing the galls are Acari with Eriophyidae (DT62, DT120, and DT279); Hemiptera with Aphididae (DT32, DT33, and DT169) and Psyllidae (DT145); Diptera with Cecidomyiidae (DT11, DT32, DT33, DT80, DT83, DT142, DT144, and DT206); and Hymenoptera with Chalcididae (DT32 and DT33), Cynipidae (DT163, DT186, and DT188), and Tenthredinidae (DT85, DT189, and DT197). Eckfeld plant hosts are the seven orders of Fabales, Fagales, Laurales, Malpighiales, Rosales, Sapindales, and Vitales, and unaffiliated taxa (Figure 5). The Eckfeld flora is comparable in gall richness to the older Early Cretaceous Rose Creek flora of the Dakota Fm, the early Paleogene Ubaté flora of the Bogotá Fm, and the younger Hindon Maar Crater flora of New Zealand (Supplementary Appendices 2, 3). The most diverse gall DTs are Cecidomyiidae (eight attributions), and the Eriophyidae, Aphididae, Cynipidae, and Tenthridinidae (three attributions each). Plant-host specimens with the most galled specimens are the unaffiliated specimens (14 occurrences), Laurales (12), and Fagales (10).

\section{Role of Global Aridification on Galler Diversity (15)}

One flora illustrating the effect on plant-insect interactions from an interval of gradual global aridification is the mid-Paleogene (37.5 Ma) Huangniuling $\mathrm{Fm}$ at localities in the Maoming and Changchang basins in, respectively, southern Guangdong, and northern Hainan, China (Kodrul et al., 2018). This study documented damage on four species of a single plant genus, the saxifragalean Liquidambar maomingensis, Liquidambar sp. 1, and Liquidambar sp. 2. and an indeterminate species of Liquidambar (sweetgum) (Dong et al., 2018). Five gall DTs representing a variety of host specificities, gall groups, and inferred galler culprits occur on Liquidambar, which includes a distinctive, elongate, deciduous gall assigned to Antronoides changchangensis, a cynipid gall (Waggoner and Poteet, 1996). If the assignment is correct, this occurrence would be oldest documented cynipid gall, although the body-fossil record of this lineage is somewhat older (Kinsey, 1919; Liu et al., 2007).
Response to the Global Expansion of Grasslands (16) The most important biological event since the $\mathrm{K}-\mathrm{Pg}$ crisis is probably the origin and expansion of grasslands that commenced toward the end of the Paleogene Period around 34 million years ago (Prasad et al., 2005) but expanded considerably during the Neogene (Edwards, 2010). Grasslands were associated with global aridification, although the timing of expansion varied from continent to continent (Edwards, 2010). In modern grasslands, the diversity of plant-insect interactions is associated with grasses (Tscharntke and Greiler, 1995) and includes external chewers (Hummelen and Gillon, 1968; Capinera and Roltsch, 1980; Quinn and Walgenbach, 1990), piercers and suckers (Hansen et al., 1985; Tscharntke, 1989), stem borers (Stiling and Strong, 1983; Moore and Clements, 1985), miners (Scheirs et al., 2001; Martin, 2007; Luginbill and Urbahns, 1916), and gallers (Ambrus and Hably, 1979; Price et al., 1987; Tscharntke, 1988, 1994; Zerova, 1978; Harris et al., 2003; De Bruyn, 2005; Skuhravá and Skuhravý, 2009; Nartshuk, 2014; Coelho et al., 2017). However, fossil galls are not associated with the fossil record of grasslands. The reasons for this are varied: (i) fossil monocots, particularly grasses, are impossible to identify without associated reproductive material such as pollen (Lee et al., 2004) or with distinctive phytoliths (Piperno and Pearsall, 1998); (ii) few fossil floras contain well-preserved grass material (Thomasson, 1982; Crepet and Feldman, 1991); and (iii) a general absence of interest. Although there is a diversity of FFGs on modern grasses, gallers are an exception. When compared to dicots, few galler taxa occur on monocots in general and grasses in particular (Mani, 1964; Raman et al., 2005; Skuhravá and Skuhravý, 2009), a consequence that also is borne out in the fossil record where there is an absence of gallers on grasses throughout the dominant 34-millionyear-long history of this highly diverse clade (Supplementary Appendix 3). By contrast, miners-the other diverse endophytic group on vascular plants-are moderately abundant on grasses (Spencer, 1990). Evidently, grass-gall associations were rarely, if ever, established in the past.

Unlike grasslands, other plant communities during this interval from 25 to 3 million years ago supported gall associations involving a broad variety of insect gallers and plant hosts. The three oldest floras during this interval are the Breitscheid Fm, Most Fm, and Dunstan Fm floras. The oldest flora, the latest Paleogene (24.8 Ma) Breitscheid Fm flora, comes from Enspel, a locality in Rhineland-Palatinate, Germany. Of the four galls from the flora, the three galls of generalized host specificity attacked Acer (maple) with high frequency, whereas specialized DT205 is a psyllid spangle gall on the lauralean Laurophyllum (Gunkel and Wappler, 2015). The next youngest flora, the early Neogene (20 Ma) Most Fm flora of the Bílina Mine, is from the Ústí nad Labem region of the Czech Republic. This flora provides 16 excellently preserved gall types, some with uncanny resemblance to their modern analogs (Table 3), attributable to extant families or genera, suggesting prolonged evolutionary stasis (Knor et al., 2013). The Most Fm is stratigraphically divided into an older, lower Holešice Member and a younger, upper Libkovice Member, the latter of which has 2.5 times the galls as the older member, attributable to a change to a colder, drier climate with seasonally variable rainfall (Bairstow et al., 2010; Knor et al., 2013). The 
third, youngest flora is the Hindon Maar Crater flora of the early Neogene (18.8 Ma) from South Island in New Zealand. Planthost specificities are $33.3 \%$ generalized, $14.3 \%$ of intermediate specificity, and $52.4 \%$ specialized, indicating a highly specialized level of galling. This flora has 21 gall DTs representing the blister, cover, erineum, pit, pouch, spangle, and unassigned blister, mark, or pit gall groups. Culprits inferred to cause the galls are Acari with Eriophyidae (DT62, DT106, DT117, and DT120); Hemiptera with Aphididae (DT32 and DT34) and Phylloxeridae (DT119); Diptera with Cecidomyiidae (DT11, DT32, DT34, DT80, and DT218); and Hymenoptera with Chalcidae (DT32 and DT34) and Tenthridinidae (DT189, DT194, and DT197). The greatest representation of inferred galler taxa are Cecidomyiidae (five attributions) and Eriophyidae (four). Of the plant hosts, $22 \%$ of specimens are galled, represented by 16 occurrences on unaffiliated hosts, 12 on Myrtales, and 12 on Fagales (12), the latter consisting of entirely Nothofagus. Except for the unaffiliated plant hosts that may represent multiple taxonomic orders (McLeish et al., 2006), the presence of Myrtales and Fagales as the dominant plant hosts suggests an earlier presence of gallers on Myrtaceae (Eucalyptus) and Nothofagaceae (Nothofagus) that presently occur in the Australian flora (Hardy and Gullan, 2010).

The five youngest floras during this interval describe fossil galls that probably have extant equivalents (Supplementary Appendix 3). The second flora, the mid-Neogene (15.5 Ma) Toupi Fm flora from the Guangchang locality of Jiangxi, China, which consists of five gall DTs, an absence of a host-plant specificity pattern, and a limited range of gall groups, inferred gallers, and unidentified plant hosts. The second flora involves a detailed study of Neogene forests of Iceland, extending in age to the past 15 million years in continuous succession, demonstrating how dramatic changes in climate have affected the distribution of plant-insect interactions, pargicularly gallers in the establishment of a distinct herbaceous layer (Wappler and Grímsson, 2016). The much younger, third flora, the late Neogene (8.2 Ma) Palo Pintado Fm flora from the Quebrado del Horno locality of Salta, Argentina, registers only three gall DTs that are on the sapindalean hosts of Cedrela (Spanish cedar) and Schinus (pepper tree). The fourth flora is from the latest Neogene (ca. 4.4 Ma) of Chuizbaia, in Maramureş, Romania, that has nine mite, aphid, and cecidomyiid galls assigned to existing genera and species, and indeterminate galls to ichnogenera (Givulescu, 1981). The fifth flora is from the latest Neogene (ca. 3.1 Ma) Willershausen deposit from Northeim, in Lower Saxony of Germany, that describes 34 mite, aphid, cecidomyiid, and cynipid galls assigned to modern genera and species, and indeterminate galls that are given ichnogenera and ichnospecies designations (Straus, 1977).

A continuation of modern gall morphologies documented from the older fossil record is present among four single and disparate occurrences of an aphid and three cecidomyiid galls, each of which occurs on the same or closely related planthost genus as their modern counterpart (Akimoto, 2004). These four, late Neogene galls (Labandeira, 2005), when collectively time-averaged, are approximately five times younger than the mid-Paleogene Messel galls, which do not share the same or closely related host-plant genera as their modern analogs (Table 2). The oldest of the Miocene galls is from the midNeogene (ca. $15 \mathrm{Ma}$ ) Latah Fm, at the Clarkia deposits of northwestern Idaho, United States (Lewis, 1985). From this deposit, 13 galls of the cecidomyiid Thecodiplosis sp. (DT179) occur on bald cypress, Taxodium sp. (Pinales: Cupressaceae), that are morphologically indistinguishable from modern $T$. cupressiananassa on T. distichum (Chen and Appleby, 1984). Another cecidomyiid association comes from the late Neogene (ca. 8.4 Ma) lignites of the La Cerdaña deposits at Lérida, in northwestern Spain (de Villalta, 1957; Diéguez et al., 1996; Barrón et al., 1999). Eight distinctive galls of the fossil cecidomyiid Mikiola pontiensis are present on a leaf of the beech Fagus pristina (Fagales: Fagaceae) that are very similar to modern Mikiola fagi on modern European beech, Fagus sylvatica (Diéguez et al., 1996), a member of the cecidomyiid galling community on Fagus that apparently no longer occurs in North America (Sato and Yukawa, 2001). Of the same age is another conifer gall from the Braunkohle deposit of the Inden Fm, near Düren,

TABLE 3 | Identifiable fossil galls associated with fossil host plants from the lower Miocene of Bílina Mine, Most Basin (Czech Republic).

\begin{tabular}{|c|c|c|c|}
\hline Plant family & Host plant species & $\begin{array}{l}\text { Taxonomic group of organisms } \\
\text { inducing fossil galls }\end{array}$ & $\begin{array}{l}\text { Recent gall-inducing species showing the } \\
\text { closest resemblance }\end{array}$ \\
\hline Cupressaceae & Taxodium dubium & Diptera: Cecidomyiidae & Taxodiomyia sp. \\
\hline Lauraceae & Daphnogene polymorpha & Acari: Eriophyidae & Eriophyes daphnogene ${ }^{2}$ \\
\hline Lythraceae & Decodon gibbosus & Diptera: Cecidomyiidae & Horidiplosis ficifolii \\
\hline Fabaceae & Podocarpium podocarpum & Diptera: Cecidomyiidae & Meunieriella aqualonia \\
\hline Betulaceae & Alnus julianiformis & Acari: Eriophyidae & Eriophyes inangulis \\
\hline Fagaceae & Quercus rhenana & Hymenoptera: Cynipidae & Cynips quercusfolii \\
\hline Fagaceae & Trigobalanopsis rhamnoides & Acari: Eriophyidae & Eriophyes sp. \\
\hline Juglandaceae & Carya sp. & Hemiptera: Phylloxeridae & Phylloxera caryaeglobuli \\
\hline Tiliaceae & Tilia brabenecii & Diptera: Cecidomyiidae & Physemocecis hartigi \\
\hline Sapindaceae & Acer angustilobium & Acari: Eriophyidae & Aceria pseudoplatani \\
\hline Sapindaceae & Acer angustilobium & Acari: Eriophyidae & Aceria macrochela \\
\hline Oleaceae & Fraxinus bilinica & Acari: Eriophyidae & Aceria fraxinicola \\
\hline Oleaceae & Fraxinus bilinica & Acari: Eriophyidae & Aculus epiphyllus \\
\hline Oleaceae & Fraxinus bilinica & Diptera: Cecidomyiidae & Dasineura fraxinea \\
\hline
\end{tabular}

1. Taken from Knor et al. (2013). Reproduced with permission.

2. An extinct species. 
North Rhine-Westphalia, Germany. This deposit provided a distinctive fossil cecidomyiid gall of Sequoiomyia kraeuseli that was present on dawn redwood Metasequoia langsdorfi (Pinales: Cupressaceae), a dipteran gall morphologically nearly identical to modern Sequoiomyia taxodii hosted by the close Metasequoia relative, the swamp cypress T. distichum (Möhn, 1960; Gagné, 1968). The last gall-plant association was from the late Neogene (ca. 6.1 Ma) lake deposit of the Oeningen Fm, near Öhningen, in Baden-Württemberg, Germany (Mädler, 1936). From this deposit a leaf of Populus latior (Malpighiales: Salicaceae) bears a Pemphigus sp. petiole gall (Mädler, 1936) that is very similar to modern Pemphigus obesinymphae on Frémont's cottonwood, Populus fremontii (Aoki and Moran, 1994; also see Akimoto, 1985). Collectively, the relationships of these four later Neogene galls with their plant hosts more or less survived intact to the present after a lapse of 5 to 15 million years.

Gallwasp (Hymenoptera: Cynipidae) galls, or galls very similar to those of gallwasps, are present in the Republic, Messel, and Eckfeld floras from 49 to 44.3 million years ago (Labandeira, 2002; Wappler et al., 2012) amid the earliest occurrences of many structurally modern galls (Table 2) (Guzicka et al., 2016). However, almost all of the extensive documentation of gallwasp galls occurs in the later Neogene, representing a time interval approximately 16 to 5 million years ago and from numerous western North American localities in California, Nevada, Oregon, Idaho, and Montana (Leckey and Smith, 2015). At least four mid-Neogene ichnospecies of the gallwasp gall Antronoides and their relationships with Fagaceae plant hosts have been established. Antronoides schorni had Quercus pollardiana (Fagales: Fagaceae) as its host; A. cyanomontanus had $Q$. simulata; $A$. oregonensis also had $Q$. simulata; and $A$. polygonalis had Q. simulata as well (Waggoner and Poteet, 1996; Waggoner, 1999). It appears that the closest modern analog to Antronoides is Cynips cornifex and that the closest modern host analogs of Antronoides are white oaks (Erwin and Schick, 2007), based on the observation that C. cornifex only galls European white oaks. Consequently, the relationship between Neogene Antronoides and its white-oak hosts was probably obligate with Q. pollardiana and Q. simulata. Earlier work and the above patterns indicate that the radiation of gallwasps may have originated in mesic forests at higher latitudes during the late Paleogene and subsequently shifted southward to oak hosts in more xeric habitats of, for example, the Great Basin, during the early Neogene (Erwin and Schick, 2007). Modern data indicate that gallwasps possessed a high level of plant-host conservatism during the past 20 million years (Stone et al., 2009; also see Cook et al., 2002). With the possible exception of specialist nepticulid, bucculatricid, and gracillariid mining clades occurring on oak hosts during the same time in western North America (Cornell, 1985; Prinzing et al., 2016), the Antronoides-Quercus system may be the best case of coevolved plant-gall system in the fossil record.

\section{Hothouse-Icehouse Cycles and the Modern World (17)}

The fossil record of plant-insect interactions is poor for the past 3 million years, of which the last $87 \%$ constitutes the Quaternary Period that consists of the older Pleistocene Epoch and younger Holocene Epoch. In particular, at higher latitudes, the several cycles of glaciation (icehouse) and deglaciation (hothouse) have eroded or otherwise prevented formation of persistent deposits during this time period, and other glacial and interglacial effects have altered deposition patterns in nonglaciated areas. For paleontologists, the most challenging aspect of the Quaternary Period is that most deposits consist of unconsolidated sediment, and not hardened sedimentary rock, resulting in processing of rock material through techniques such as dry or water sieving and washing of sediment rather than the splitting of rock. The fossil gall record, in part, reflects these challenges and is confined to an early Pleistocene occurrence and several occurrences during the Late Pleistocene interval, from 129,000 years to $11,700 \mathrm{BP}$ and the latter part of the Holocene interval since $11,700 \mathrm{BP}$.

The early Pleistocene (2.1 Ma) Bernasso diatomites near Lodève, in Hérault, France, preserve a forest whose plantinsect interactions were dominated by galling (Adroit et al., 2016). Galling was represented by seven DTs, 19 planthost species, and $30 \%$ of the interactions at Bernasso; the most frequent gall was DT32 and the most frequently galled host was the saxifragalean Parrotia persica. The highfrequency but non-diverse pattern of galling at Bernasso could indicate a late-successional forest, a low mean annual temperature, or high mean annual precipitation (Adroit et al., 2016), or possibly a combination of these indicators. The forest at Bernasso is physiognomically closest to the modern forest along the Iranian coast of the Caspian Sea that also supports the endemic P. persica as a dominant plant (Adroit et al., 2018). Notably, modern P. persica has considerably less specialized damage, including galls, than its early Pleistocene conspecific, suggesting a currently suboptimal environment. One of the few studies encompassing the Pleistocene (Su et al., 2015) demonstrates the resilience of an oak lineage and its insect associates, including gallers, in Southwestern China.

Most gall-bearing sites during the late Pleistocene and Holocene reflect deposits where plant fragments or individual galls are found dispersed through the sediment and detached from their plant host and consequently are discovered mostly through sieving of sediment. Examples from the Late Pleistocene include cecidomyiid galls referable to Retinodiplosis and Itonida from a Taxodium swamp deposit from the District of Columbia, United States (Berry, 1924); cynipid galls attributable to Andricus sp. from a gravel pit near Raalte, Overijssel Province, Netherlands (Stone et al., 2008); galls assigned to the Cynipinae from the Rancho La Brea tar pits in Los Angeles, CA, United States (Miller, 1997; Holden et al., 2015); and probable Cecidomyia salicis stem galls on the willow Salix amygdalina (Malpighiales: Salicaceae) from the Stegodon beds at Yagi-Higashiei, Japan (Miki, 1937). From the Holocene Epoch are cynipid galls comparable to Andricus and Neuroterus from a fourth century A.D. Roman well near Abindon, Oxfordshire, United Kingdom (Robinson, 1980). Patterns of gall occurrences in Quaternary localities often provide important data in marshaling historical biogeographical data for understanding the current distributions of gall insects and their plant hosts (Stone et al., 2008; Mutun and Dinç, 2019). 


\section{DISCUSSION}

This review provides two obvious issues that are addressed below. First, as this review has emphasized the gall trace-fossil record, how do these data compare with the gall body-fossil record? Second, what are the major gaps in our understanding of the gall trace-fossil record? Another obvious issue is how does the trace-fossil record of galls compare with the trace-fossil record of mines, the other diverse endophytic FFG. However, the latter question should be addressed in an appropriate review of the mine fossil record.

\section{How Does the Gall Body-Fossil Gall Record Compare With the Galler Trace-Fossil Record?}

One perspective on the past history of galling insects is an assessment of the two basic types of evidence that the fossil record offers. The first type of data are body fossils of the insects themselves, that is, preserved bodies of insect gallers whether they are compressed on a slab of shale or entombed in amber. The second type of data involves the effects of insects on the plants themselves, whether these effects are termed trace fossils, ichnofossils, plant damage, or insect extended phenotypes that are preserved as galls or gall-like phenomena. There are advantages and disadvantages to each of these categories of fossils.

The continental (terrestrial and fresh water) fossil record is very spotty through time, for both body fossils (Schachat et al., 2019) and trace fossils (Minter et al., 2016). Almost all insect and mite fossils are confined to exceptional fossil deposits that occur very infrequently in time and space, with major stretches of geological time and certain geographic regions bereft of such deposits. Indeed, the insect fossil record is driven by such exceptional deposits (Labandeira and Sepkoski, 1993); examples include the Wellington Fm from the early Permian of Kansas, the Yixian Fm from the Early Cretaceous of northeastern China, mid-Cretaceous Myanmar Amber, and Paleogene Baltic Amber from northern Europe (Selden and Nudds, 2012). This fossil record consists of three major groups of continental fossils: vascular plants (Gerrienne et al., 2016), arthropods (Ward et al., 2006), and fungi (NaranjoOrtiz and Gabaldón, 2019), a consequence of only a limited number marine lineages that became terrestrialized, resulting in three hyperdiverse groups that essentially structure fossil ecosystems on land. Of these three hyperdiverse groups on land, vascular plants are, by far, the most abundant on land for several reasons. First, as primary producers and the base of terrestrial food webs, plants typically are an order of magnitude more abundant than their consumers, such as arthropods by measures such as biomass or energy (Odum, 1968). Second, plants have a maximum size that exceeds that of arthropods and fungi by orders of magnitude and are the most conspicuous organisms in ecosystems. Third, the modularity of plants allows their usual preservation as organs such as stems, leaves, seeds, and roots, that are not as available for arthropods and fungi (Chomicki et al., 2017), resulting in the excessive multiplication of organs, particularly leaves, from the same individual.

These three properties of fossil plants are responsible for the inordinate numbers of leaves in the fossil record that allow the trace-fossil record of galls to be more informative about the life habits of gallers than the fewer numbers of preserved galling insects. The Cecidomyiidae, the most diverse family of galling insects (Gagné, 1989), is an important case. The body fossil record of galling Cecidomyiidae is almost entirely confined to amber deposits, principally Early Cretaceous Álava amber (Arillo and Nel, 2000), Late Cretaceous Taimyr amber (Fedotova and Perkovsky, 2016), mid-Paleogene Baltic amber (Nel and Prokop, 2006; Fedotova, 2014), late Paleogene Rovno amber (Perkovsky and Fedotova, 2004, 2008; Fedotova and Perkovsky, 2015), late Paleogene Mexican Amber (Fedotova and Perkovsky, 2019), and late Paleogene Dominican amber (Fedotova and Perkovsky, 2007, 2019). However, the Cecidomyiidae trace-fossil record is almost entirely restricted to the compression-impression fossil record from many plant communities different from those represented by amber deposits. These compression-impression deposits include the early Cretaceous Dakota Fm (Xiao and Labandeira, 2020: personal observation); the K-Pg boundary intervals of North Dakota, United States (Labandeira et al., 2002a,b; Donovan et al., 2014) and Patagonia, Argentina (Donovan et al., 2016, 2018); early Paleogene of Patagonia (Donovan et al., 2016, 2018); early Paleogene of India (Srivastava et al., 2000; Banerji, 2004; Raman et al., 2009); mid-Paleogene of Washington state (Labandeira, 2002); two deposits from the mid-Paleogene of Germany (Wappler et al., 2012; Kunzmann et al., 2019); early Neogene of the Czech Republic (Knor et al., 2013); and early Neogene of New Zealand (Möller et al., 2019). These deposits represent deltaic, fluvial, lacustrine, and paludal environments rarely represented in amber. However, there are other advantages of the gall trace-fossil record versus the gall body-fossil record (Labandeira, 2007b), other than a greater representation of diverse plant communities and habitats.

There are three other benefits of the gall trace-fossil record (Labandeira, 2007b). Because of the ubiquity of leaves over insects in the fossil record, trace-fossil data frequently reveal that particular plant-gall associations occur earlier in geologic time than the body-fossil record of the same galling lineage would indicate. Second, plant-gall trace fossil data provide valuable behavioral data, such as host-plant associations and levels of specialization, which are almost always unavailable from body fossils. Finally, plant-gall trace-fossil data can supply crucial data for testing ecological hypotheses, such as the role of habitat in the evolution of gall morphology, which would be absent by resorting to body-fossil data alone. Another use of plant-gall trace fossil data would be to test the hypothesis that extant gall diversity is supported by extant diversity of their plant hosts rather than the age of those same gall host lineages (Fernandes, 1992). The major disadvantage of the gall trace-fossil record is the challenge in attempting to identify gall culprits, minus potential instances where a galler inhabitant occurs within a fossil gall (Nishida and Hayashi, 1996). However, in the mid-Paleogene to recent part of the fossil record, gall morphologies are often so distinct and 
plant-host relationships are so evident that an attribution can be made with a high level of confidence (Tables 2, 3).

\section{Current Research Gaps}

This overview of the fossil gall record of insects and mites has shown that several major research gaps exist in the data. The major absences of data involve certain time periods, particular paleocontinents and continents, and missing ecosystems. For missing time periods (Figures 1, 2, 4), an approximate 60million-year-long gap is missing from the Middle Devonian to the Mississippian-Pennsylvanian boundary; other gaps are present for about 7 million years in the early Triassic, about a 25-million-year-long interval for much of the Late Cretaceous, and, ironically, the past 3 million years. There are major absences for major continental masses deployed as older paleocontinents and more recent continents (Figures 3, 5). The largely Paleozoic paleocontinent of Angara, currently constituting much of central Russia, is not represented; Cathaysia is very poorly represented; and the Gondwanan continents of India, Madagascar, Antarctica, and much of Africa have very few studies (Adami-Rodrigues et al., 2004; McLoughlin et al., 2015; Srivastava and Srivastava, 2016). There are ecosystems, communities, and habitats that are not represented in the plant-gall fossil record. Upland ecosystems, including montane, glacier associated, and desert habitats, largely are not present in the fossil record. A future research agenda would be to sample the fossil gall record from a variety of ecological settings to test proposed evolutionary hypotheses regarding gall insects (Fernandes, 1992; Ward et al., 2003; Wappler et al., 2009; Hardy and Cook, 2010; Araújo, 2013; Carvalho et al., 2014).

\section{CONCLUSION}

The fossil record is a rich source of data for understanding the evolutionary and ecological history of insect and mite galls. However, the fossil gall record requires an appreciation of how galls become preserved, the history of their plant hosts, gall

\section{REFERENCES}

Adami-Rodrigues, K., Iannuzzi, R., and Pinto, I. D. (2004). Permian plant-insect interactions from a Gondwana flora of southern Brazil. Foss. Strata 51, 106-125.

Adroit, B., Malekosseini, M., Girard, V., Abedi, M., Rajaei, H., Terral, J.-F., et al. (2018). Changes in the pattern of plant-insect interactions on the Persian ironwood (Parrotia persica, Hamamelidaceae) over the last 3 million years. Rev. Palaeobot. Palynol. 258, 22-35. doi: 10.1016/j.revpalbo.2018.06.007

Adroit, B., Wappler, T., Terral, J.-F., Ali, A. A., and Girard, V. (2016). Bernasso, a paleoforest from the early Pleistocene: new input from plant-insect interactions (Hérault, France). Palaeogeogr. Palaeoclim. Palaeoecol. 446, 78-84. doi: 10. 1016/j.palaeo.2016.01.015

Akimoto, S. (1985). Taxonomic study on gall aphids, Colopha, Paracolopha and Kaltenbachiella (Aphidoidea: Pemphigidae) in East Asia, with special reference to their origins and distributional patterns. Ins. Matsum. 31, 1-79.

Akimoto, S. (2004). "Phylogeny, evolution and biogeography of gall-forming aphids (Insecta: Homoptera): a case study from the Eriosomatini," in Proceedings of the International Symposium on "Dawn of a New Natural morphological trends through time, and the relationship between the trace-fossil record of galls-the emphasis of this reviewand the body fossil record of their gallers. Proposed hypotheses regarding the evolutionary history of gall insects can be addressed by investigating the trace-fossil and body-fossil record that likely would provide novel insights into this fascinating group of insects, mites, and their plant hosts.

\section{AUTHOR CONTRIBUTIONS}

The author confirms being the sole contributor of this work and has approved it for publication. The author is responsible for the drawing and rendering of all figures.

\section{ACKNOWLEDGMENTS}

I thank Ananthanaryanan Raman, Donald Miller, and Makoto Tokuda for inviting me to provide this contribution. I am grateful to Diane Erwin and Torsten Wappler for providing highly relevant reviews of this manuscript. Jennifer Wood is thanked for her formatting of the figures; all drawings of galls were made by the author. This is contribution 379 of the Evolution of Terrestrial Ecosystems consortium at the National Museum of Natural History in Washington, DC, United States.

\section{SUPPLEMENTARY MATERIAL}

The Supplementary Material for this article can be found online at: https://www.frontiersin.org/articles/10.3389/fevo.2021. 632449/full\#supplementary-material

Supplementary Appendix 1 | The biologies of gall damage types (DTs) in time and space: Paleozoic Occurrences.

Supplementary Appendix 2 | The biologies of gall damage types (DTs) in time and space: Mesozoic Occurrences.

Supplementary Appendix 3 | The biologies of gall damage types (DTs) in time and space: Cenozoic Occurrences.

History - Integration of Geoscience and Biodiversity Studies, eds S. F. Mawatari and H. Okada (Sapporo: Hokkaido University), 19-26.

Álvarez, R., González-Sierra, S., Candelas, A., and Martínez, J.-J. I. (2013). Histological study of galls induced by aphids on leaves of Ulmus minor: Tetraneura ulmi induces globose galls and Eriosoma ulmi induces pseudogalls. Arthro. Pl. Interact. 7, 643-650. doi: 10.1007/s11829-013-9278-8

Alvin, K. L., Barnard, P. D. W., Harris, T. M., Hughes, N. F., Wagner, R. H., and Wesley, A. (1967). "Gymnospermophyta," in The Fossil Record, eds W. B. Harland, C. H. Holland, M. R. House, N. F. Hughes, M. Reynolds, M. J. S. Rudwick, et al. (London: Geological Society of London).

Ambrus, B., and Hably, L. (1979). Eriophyes daphnogene sp. n., a fossil from the Upper Oligocene in Hungary. Annal. Histor. Nat. Musei Nat. Hungar. 71, 55-56.

Ananthakrishnan, T. N., and Raman, A. (1989). Thrips and Gall Dynamics. Leiden: Brill.

Anderson, J. M., and Anderson, H. M. (1985). Palaeoflora of Southern Africa. Prodromus of South African Megafloras Devonian to Lower Cretaceous. Rotterdam: Balkema. 
Anderson, J. M., and Anderson, H. M. (1989). Palaeoflora of Southern Africa: Molteno Formation (Triassic): Gymnosperms Excluding Dicroidium, Vol. 2. Rotterdam: Balkema.

Aoki, S., and Moran, N. A. (1994). Pemphigus obesinymphae, a new American aphid species with defenders and swollen nymphs (Homoptera: Aphidoidea: Pemphigidae). J. N.Y. Entomol. Soc. 102, 251-260.

Araújo, W. S. (2013). Different relationships between galling and non-galling herbivore richness and plant species richness: a meta-analysis. Arthro. Pl. Interact. 7, 373-377. doi: 10.1007/s11829-013-9259-y

Arillo, A., and Nel, A. (2000). Two new fossil cecidomyiids flies from the Lower Cretaceous amber of Álava (Spain) (Diptera. Cecidomyiidae). Bull. Soc. Entomol. France 105, 285-288.

Ash, S. R. (1972). Late Triassic plants from the Chinle Formation in north-eastern Arizona. Palaeontology 15, 598-618.

Ash, S. R. (1997). Evidence of arthropod-plant interactions in the Upper Triassic of the southwestern United States. Lethaia 29, 237-248.

Bairstow, K. A., Clarke, K. L., McGeoch, M. A., and Andrew, N. R. (2010). Leaf miner and plant galler species richness on Acacia: relative importance of plant traits and climate. Oecologia 163, 437-448. doi: 10.1007/s00442-010-1606-4

Banerjee, M., and Bera, S. (1998). Record of zoocecidia on leaves of Glossopteris browniana Brong. From Mohuda Basin, Upper Permian, Indian Lower Gondwana. Ind. Biol. 30, 58-61.

Banerji, J. (2004). Evidence of insect-plant interactions from the Upper Gondwana sequence (Lower Cretaceous) in the Rajmahal Basin. India. Gond. Res. 7, 205-210. doi: 10.1016/s1342-937x(05)70320-8

Barrón, E., Arillo, A., and Diéguez, C. (1999). El Mioceno Superior de la Cuenca de la Cerdaña (Pirineos orientales). Temas Geológico-Mineiros. Inst. Tecnol. Geomin. Esp. 26, 63-69.

Beck, A. L., and Labandeira, C. C. (1998). Early Permian insect folivory on a gigantopterid-dominated riparian flora from north-central Texas. Palaeogeogr. Palaeoclim. Palaeoecol. 142, 139-173. doi: 10.1016/S0031-0182(98)00060-1

Beckemeyer, R. J. (2004). A new species of the extinct family Lophioneuridae from the Lower Permian Wellington Formation of Noble County, Oklahoma. J. Kans. Entomol. Soc. 77, 132-136. doi: 10.2317/0306.12.1

Bernardi, M., Petti, F. M., Kustatscher, E., Franz, M., Hartkopf-Fröder, C., Labandeira, C. C., et al. (2017). Late Permian (Lopingian) terrestrial ecosystems: a global comparison with new data from the low-latitude Bletterbach Biota. Ear. Sci. Rev. 175, 18-43. doi: 10.1016/j.earscirev.2017.10.002

Berry, E. W. (1924). Organic remains, other than diatoms, from the excavation. J. Wash. Acad. Sci. 14, 1-3.

Berry, J. A. (1997). Nematus oligospilus (Hymenoptera: Tenthredinidae), a recently introduced sawfly defoliating willows. $N$ Z. Entomol. 20, 51-54. doi: 10.1080/ 00779962.1997.9722670

Bird, J., Faith, D. P., Rhomberg, L., Riska, B., and Sokal, R. R. (1979). The morphs of Pemphigus populitransversus: allocation methods, morphometrics, and distribution patterns. Ann. Entomol. Soc. Amer. 72, 767-774. doi: 10.1093/ aesa/72.6.767

Boczek, J., and Shevchenko, V. G. (1996). Ancient associations: eriophyoid mites on gymnosperms. World Crop Pests 6, 217-226. doi: 10.1016/s1572-4379(96) 80012-1

Briones, M. L. (1976). The eriophyid plant mites of South Dakota. So. Dakota Agric. Expt. Sta. Tech. Bull. 43, 1-123.

Bronner, R. (1992). "The role of nutritive cells in the nutrition of cynipids and cecidomyiids," in Biology of Insect-Induced Galls, eds J. D. Shorthouse and O. Rohfritsch (New York, NY: Oxford University Press), $118-140$.

Brooks, H. K. (1955). Healed wounds and galls on fossil leaves from the Wilcox deposits (Eocene) of Western Tennessee. Psyche 62, 1-9. doi: 10.1155/1955/ 76727

Capinera, J. L., and Roltsch, W. J. (1980). Response of wheat seedlings to actual and simulated migratory grasshopper defoliation. J. Econ. Entomol. 73, 258-261. doi: $10.1093 /$ jee/73.2.258

Cariglino, B. (2020). Patterns of insect-mediated damage in a Permian Glossopteris flora from Patagonia (Argentina). Palaeogeogr. Palaeoclim. Palaeoecol. 507, 39-51. doi: 10.1016/j.palaeo.2018.06.022

Carleton, M. (1938). The biology of Potania proxima Lep., the bean gall sawfly of willows. Zool. J. Linn. Soc. 40, 20-21.
Carneiro, M. A. A., Fernandes, G. W., and De Souza, O. F. F. (2005). Convergence in the variation of local and regional galling species richness. Neotrop. Entomol. 34, 547-553. doi: 10.1590/s1519-566x2005000400003

Carvalho, M. R., Jaramillo, C., Parra, F., de la Caballero, D., Herrera, F., Wing, S., et al. (2021). Extinction at the end Cretaceous set the origin of modern Neotropical rainforests. Science 372, 63-68. doi: 10.1126/science.abf1969

Carvalho, M. R., Wilf, P., Barrios, H., Windsor, D. M., Currano, E. M., Labandeira, C. C., et al. (2014). Insect leaf chewing damage tracks herbivore richness in modern and ancient forests. PLoS One 9:e94950. doi: 10.1371/journal.pone. 0094950

Cenci, R., and Adami-Rodrigues, K. (2019). Record of gall abundance as a possible episode of radiation and speciation of galling insects, Triassic, southern Brazil. Rev. Bras. Paleontol. 20, 279-286. doi: 10.4072/rbp.2017.3.01

Charles, J. G., and Allan, D. J. (2000). Development of the willow sawfly, Nematus oligospilus, at different temperatures, and an estimation of voltinism throughout New Zealand. N. Z. J. Zool. 27, 197-200. doi: 10.1080/03014223.2000.951 8226

Chen, C.-N., and Appleby, J. E. (1984). Biology of the cypress twig gall midge, Taxodiomyia cupressiananassa (Diptera: Cecidomyiidae), in central Illinois. Ann. Entomol. Soc. Am. 77, 203-207. doi: 10.1093/aesa/77.2.203

Chinery, M. (2011). Britain's Plant Galls: A Photographic Guide. Hampshire: British Plant Gall Society.

Chomicki, G., Coiro, M., and Renner, S. S. (2017). Evolution and ecology of plant architecture: integrating insights from the fossil record, extant morphology, developmental genetics and phylogenies. Ann. Bot. 120, 855-891. doi: 10.1093/ $\mathrm{aob} / \mathrm{mcx} 113$

Clancy, K. M., Price, P. W., and Craig, T. P. (1986). Life history and natural enemies of an undescribed sawfly near Pontania pacifica (Hymenoptera: Tenthredinidae) that forms leaf galls on arroyo willow, Salix lasiolepis. Ann. Entomol. Soc. Amer. 79, 884-892. doi: 10.1093/aesa/79.6.884

Coelho, M. S., Carneiro, M. A. A., Branco, C. A., Borges, R. A. X., and Fernandes, G. W. (2017). Galling insects of the Brazilian Páramos: species richness and composition along high-altitude grasslands. Environ. Entomol. 20:147. doi: 10. 1093/ee/nvx147

Connor, E. F., and Taverner, M. P. (1994). The evolution and adaptive significance of the leaf-mining habit. Oikos 79, 6-25. doi: 10.2307/3546085

Cook, J. M., Rokas, A., Pagel, M., and Stone, G. N. (2002). Evolutionary shifts between host oak sections and host-plant organs in Andricus gallwasps. Evolution 56, 1821-1830. doi: 10.1554/0014-3820(2002)056[1821:esbhos]2.0. co;2

Cook, L. G., and Gullan, P. J. (2004). The gall-inducing habit has evolved multiple times among the eriococcid scale insects (Sternorrhyncha: Coccoidea: Eriococcidae). Biol. J. Linn. Soc. 83, 441-452. doi: 10.1111/j.1095-8312.2004. 00396.x

Cornell, H. V. (1985). Local and regional richness of cynipine gall wasps on California oaks. Ecology 66, 1247-1260. doi: 10.2307/1939178

Correia, P., Bashforth, A. R., Šimůnek, Z., Cleal, C. J., and Labandeira, C. C. (2020). The history of herbivory on sphenophytes: a new calamitalean with an insect gall from the Upper Pennsylvanian of Portugal and a review of arthropod herbivory on an ancient lineage. Int. J. Plant Sci. 183, 387-418. doi: $10.1086 / 707105$

Crepet, W. L., and Feldman, G. W. (1991). The earliest remains of grasses in the fossil record. Am. J. Bot. 78, 1010-1014. doi: 10.1002/j.1537-2197.1991. tb14506.x

Currano, E. D. (2019). "Paper 32: response of plant-insect associations to Paleocene-Eocene warming (1999) P. Wilf and C. C. Labandeira commentary," in Foundations of Paleoecology, eds S. K. Lyons, A. K. Behrensmeyer, and P. J. Wagner (Chicago, IL: University of Chicago Press), 531-532.

Currano, E. D., Labandeira, C. C., and Wilf, P. (2010). Fossil insect folivory tracks paleotemperature for six million years. Ecol. Monogr. 80, 547-567.

Currano, E. D., Pinheiro, E. R. S., Buchwaldt, R., Clyde, W. C., and Miller, I. M. (2019). Endemism in Wyoming plant and insect herbivore communities during the early Eocene hothouse. Paleobiology 45, 421-439. doi: 10.1017/pab.2019.18

Currano, E. D., Wilf, P., Wing, S. L., Labandeira, C. C., Lovelock, E. C., and Royer, D. L. (2008). Sharply increased insect herbivory during the Paleocene-Eocene Thermal Maximum. Proc. Natl. Acad. Sci. U.S.A. 105, 1960-1964. 
Darlington, A. (1975). The Pocket Encyclopaedia of Plant Galls in Colour. Poole: Blandford Press.

De Bruyn, L. (2005). "Biology, ecology, and evolution of shoot flies (Diptera: Chloropidae)," in Biology, Ecology, and Evolution of Gall-Inducing Arthropods, eds A. Raman, C. W. Shaefer, and T. M. Withers (Enfeld, NH: Science Publishers), 373-405.

de Villalta, J. F. (1957). Dos zoocecidías fósiles del Mioceno de Cerdaña (prov. de Lérida). Cursil. Conferen. Instit. Lucas Mall. 4:1.

Diéguez, C., Nieves-Aldrey, J. L., and Barrón, E. (1996). Fossil galls (zoocecids) from the upper Miocene of La Cerdaña (Lérida, Spain). Rev. Palaeobot. Palynol. 94, 329-343.

Ding, Q., Labandeira, C. C., Meng, Q., and Ren, D. (2015). Insect herbivory, plant-host specialization and tissue partitioning on mid-Mesozoic broadleaved conifers of Northeastern China. Palaeogeogr. Palaeoclim. Palaeoecol. 440, 259273.

Dong, J., Sun, B., Mao, T., Yan, D., Liu, C., Wang, Z., et al. (2018). Liquidambar (Altingiaceae) and associated insect herbivory from the Miocene of southeastern China. Palaeogeogr. Palaeoclim. Palaeoecol. 497, 11-24. doi: 10.1016/j.palaeo.2018.02.001

Donovan, M. P., Iglesias, A., Wilf, P., Labandeira, C. C., and Cúneo, N. R. (2016). Rapid recovery of Patagonian plant-insect associations after the endCretaceous extinction. Nat. Ecol. Evol. 1:0012.

Donovan, M. P., Iglesias, A., Wilf, P., Labandeira, C. C., and Cúneo, N. R. (2018). Diverse plant-insect associations from the latest Cretaceous and early Paleocene of Patagonia, Argentina. Ameghiniana 55, 303-338. doi: 10.5710/ amgh.15.02.2018.3181

Donovan, M. P., Wilf, P., Iglesias, A., Cúneo, N. R., and Labandeira, C. C. (2020). Persistent biotic interactions of a Gondwanan conifer from Cretaceous Patagonia to modern Malesia. Commun. Biol. 3:708. doi: 10.1038/s42003-02001428-9

Donovan, M. P., Wilf, P., Labandeira, C. C., Johnson, K. R., and Peppe, D. J. (2014). Novel insect leaf-mining after the end-Cretaceous extinction and the demise of Cretaceous leaf miners, Great Plains, USA. PLoS One 9:e103542. doi: 10.1371 /journal.pone. 0103542

Dreger-Jauffret, F., and Shorthouse, J. D. (1992). "Diversity of gall-inducing insects and their galls," in Biology of Insect-Induced Galls, eds J. D. Shorthouse and O. Rohfritsch (New York, NY: Oxford University Press), 8-33.

Dunn, M. T., Rothwell, G. W., and Mapes, G. (2003). On Paleozoic plants from marine strata: Trivenia arkansana (Lyginopteridiaceae) gen. et sp. nov., a lyginopterid from the Fayetteville Formation (Middle Chesterian/Upper Mississippian) of Arkansas, USA. Am. J. Bot. 90, 1239-1252. doi: 10.3732/ajb. 90.8.1239

Dunne, J. A., Labandeira, C. C., and Williams, R. J. (2014). Highly resolved early Eocene food webs show development of modern trophic structure after the endCretaceous extinction. Proc. Roy. Soc. B 281:20133280. doi: 10.1098/rspb.2013. 3280

Edwards, E. J. (2010). The origins of C4 grasslands: integrating evolutionary and ecosystem science. Science 328, 587-591. doi: 10.1126/science.117 7216

Enuschchenko, I. V., and Frolov, A. O. (2020). Revision of existing classification of fossil insect feeding traces and description of new ichnotaxa from Middle Jurassic sediments of Eastern Siberia (Russia). Zootaxa 4758, 347-359. doi: 10.11646/zootaxa.4758.2.8

Erwin, D. M., and Schick, K. N. (2007). New Miocene oak galls (Cynipini) and their bearing on the history of cynipid wasps in western North America. J. Paleontol. 81, 568-580. doi: 10.1666/05031.1

Espírito-Santo, M. M., and Fernandes, G. W. (2007). How many species of gallinducing insects are there on earth, and where are they? Ann. Entomol. Soc. Am. 100, 95-99.

Fedotova, Z. A. (1997). Review of gall midges (Diptera, Cecidomyiidae) developing on Rubiaceae with description on new species from Kazakhstan. Communication 1. Zool. Zh. 76, 43-51.

Fedotova, Z. A. (2014). Classification of the gall midge tribe Aphidoletini (Diptera, Cecidomyiidae: Aphidoletidi) with descriptions of a new genus and a new species from the Kurile Islands. Entomol. Rev. 94, 1031-1051. doi: 10.1134/ s0013873814070124
Fedotova, Z. A., and Perkovsky, E. E. (2007). New gall midges of the subfamily Lestremiinae (Diptera, Cecidomyiidae) from the Rovno Amber. Paleontol. J. 41, 437-450. doi: 10.1134/s0031030107040107

Fedotova, Z. A., and Perkovsky, E. E. (2015). New gall midges (Diptera, Cecidomyiidae, Somatosematidi, Brachineuridi) from the Late Eocene amber of Gulyanka (Zhitomir Region, Ukraine). Paleontol. J. 49, 270-278. doi: 10.1134/ s0031030115030041

Fedotova, Z. A., and Perkovsky, E. E. (2016). First gall midges (Diptera, Cecidomyioidea) from Late Cretaceous amber of the Taimyr Peninsula. Paleontol. J. 50, 1001-1026. doi: 10.1134/s0031030116090033

Fedotova, Z. A., and Perkovsky, E. E. (2019). First findings of gall midges (Diptera, Cecidomyioidea, Cecidomyiidae) of the tribes Karshomyiini (Mexican Amber) and Bremiini (Dominican Amber). Paleontol. J. 53, 1060-1073. doi: 10.1134/ s0031030119100058

Fernandes, G. W. (1992). Plant family size and age effects on insular gall-forming species richness. Glob. Ecol. Biogeogr. Lett. 2, 71-74. doi: 10.2307/2997508

Fernandes, G. W., and Price, P. W. (1992). The adaptive significance of insect gall distribution: survivorship of species in xeric and mesic habitats. Oecologia 76, 161-167. doi: 10.1016/s0140-1963(18)31529-5

Fernández, J. A., and Chiesa, J. O. (2020). Plant-insect interactions in the fossil flora of the Bajo de Veliz Formation (Gzhelian-Asselian): San Luís, Argentina. Ichnos 27, 156-166. doi: 10.1080/10420940.2019.1697263

Filho, E. B. S., Adami-Rodrigues, K., Lima, F. J., Bantim, R. A. M., Wappler, T., and Saraiva, A. Á. F. (2017). Evidence of plant-insect interaction in the Early Cretaceous flora from the Crato Formation, Araripe Basin, northeast Brazil. Hist. Biol. 7, 926-937. doi: 10.1080/08912963.2017.1408611

Florin, R. (1945). Die Koniferen des Oberkarbons und des unteren Perms. Palaeontographica Abt. B Paläophytologie 85, 1-30. doi: 10.1515/9783111561 752-001

Formiga, A. T., Soares, G. L. G., and Isias, R. M. S. (2011). Responses of the host plant tissues to gall induction in Aspidosperma spruceanum Müell. Arg. (Apocynaceae). Amer. J. Plant Sci. 2, 823-834. doi: 10.4236/ajps.2011.26097

Gagné, R. J. (1968). Revision of the gall midges of bald cypress (Diptera: Cecidomyiidae). Entomol. News 79, 269-274.

Gagné, R. J. (1989). The Plant-Feeding Gall Midges of North America. Ithaca, NY: Cornell University Press.

Genise, J., Bertling, M., Braddy, S. J., Bromley, R. G., Mikuláš, R., Nielsen, K. S. S., et al. (2004). Comments on the draft proposal to amend the Code with respect to trace fossils. Bull. Zool. Nomen. 60, 35-37.

Gerrienne, P., Servais, T., and Vecoli, M. (2016). Plant evolution and terrestrialization during Palaeozoic times-The phylogenetic context. Rev. Palaeobot. Palynol. 227, 4-18. doi: 10.1016/j.revpalbo.2016.01.004

Ghosh, A. K., Kar, R., and Chatterjee, R. (2015). Leaf galls on Dicroidium hughesii (Feistmantel) Lele from the Triassic of India-a new record. Alcheringa 39, 92-98. doi: 10.1080/03115518.2015.958285

Giraldo, A., Labandeira, C. C., Herrera, F., and Carvalho, M. (2021). Rich and specialized plant-insect associations in a mid late Paleocene $(58-60 \mathrm{Ma})$ Neotropical rainforest (Bogota Formation), Colombia. Ameghiniana 58, 75-99.

Giron, D., Huguet, E., Stone, G. N., and Body, M. (2016). Insect-induced effects on plants and possible effectors used by galling and leaf-mining insects to manipulate their host-plant. J. Ins. Physiol. 84, 70-89. doi: 10.1016/j.jinsphys. 2015.12.009

Givulescu, R. (1981). Pathological elements on fossil leaves from Chuizbaia (galls, mines and other insect traces). Dãri Seamã Sedinţ. Instit. Geol. Geof. (Paleontol.) $68,123-133$.

Grauvogel-Stamm, L. (1978). La flore du Grès-à-Voltzia (Buntsandstein Supérieur) des Vosges du Nord (France): morphologie, anatomie, interpretations phylogénique et paléogéographique. Mém. Sci. Géol. France 50, 1-225.

Grauvogel-Stamm, L., and Kelber, K.-P. (1996). Plant-insect interactions and coevolution during the Triassic in Western Europe. Paleontol. Lomb. 5, 5-23.

Gunkel, S., and Wappler, T. (2015). Plant-insect interactions in the upper Oligocene of Enspel (Westerwald, Germany), including an extended mathematical framework for rarefaction. Palaeobio. Palaeoenv. 95, 55-75. doi: 10.1007/s12549-014-0176-6

Guzicka, M., Karolewski, P., and Giertych, K. J. (2016). Structural modification of Quercus petraea leaf caused by Cynips quercusfolii-histological study of galls. J. Plant Interact. 12, 7-13. 
Habgood, K. S., Hass, H., and Kerp, H. (2003). Evidence for an early terrestrial food web: coprolites from the Early Devonian Rhynie chert. Trans. R. Soc. Edinburgh (Earth Environ. Sci.) 94, 371-389. doi: 10.1017/s0263593303000269

Hansen, J. D., Asay, K. H., and Nielson, D. C. (1985). Feeding preference of a black grass bug, Labops hesperius (Hemiptera: Miridae), for 16 range grasses. J. Kans. Entomol. Soc. 58, 356-359.

Hardy, N. B., and Cook, L. G. (2010). Gall-induction in insects: evolutionary deadend or speciation driver? BMC Evol. Biol. 10:257. doi: 10.1186/1471-2148-10257

Hardy, N. B., and Gullan, P. J. (2010). Australian gall-inducing scale insects on Eucalyptus: revision of Opisthoscelis Schrader (Coccoidea, Eriococcidae) and descriptions of a new genus and nine new species. ZooKeys 58, 1-74.

Harris, K. M. (1994). Gall midges (Cecidomyiidae): classification and biology. Syst. Assn. Spe. Vol. 49, 201-211.

Harris, M., Stuart, J. J., Mohan, M., Nair, S., Lamb, R. J., and Rohfritsch, O. (2003). Grasses and gall midges: plant defense and insect adaptation. Annu. Rev. Entomol. 48, 549-577. doi: 10.1146/annurev.ento.48.091801.112559

Harris, T. M. (1942). Wonnacottia, a new bennettitalean microsporophyll. Ann. Bot. 6, 577-592. doi: 10.1093/oxfordjournals.aob.a088422

Herrera, F., Shi, G., Ichinnorov, N., Takahashi, M., Bugdaeva, E., Herendeen, P. S., et al. (2017). The presumed ginkgophyte Umaltolepis has seed-bearing structures resembling those of Peltaspermales and Umkomasiales. Proc. Natl. Acad. Sci. U.S.A. 114, E2385-E2391.

Hickey, L. J., and Doyle, J. A. (1977). Early Cretaceous fossil evidence for angiosperm evolution. Bot. Rev. 43, 2-104.

Hochuli, P. A., Hermann, E., Vigran, J. O., Bucher, H., and Weissert, H. (2010). Rapid demise and recovery of plant ecosystems across the end-Permian extinction event. Glo. Planet. Ch. 24, 144-155. doi: 10.1016/j.gloplacha.2010. 10.004

Holden, A. R., Erwin, D. M., Schick, K. N., and Gross, J. (2015). Late Pleistocene galls from the La Brea Tar Pits and their implications for cynipine wasp and native plant distribution in southern California. Quat. Res. 84, 358-367. doi: 10.1016/j.yqres.2015.09.008

Humbert, H. (1945). Une curieuse anomalie par torsion chez Equisetum ramosissimum Desf. Bull. Soc. Bot. France 92, 45-46. doi: 10.1080/00378941. 1945.10834391

Hummelen, P., and Gillon, Y. (1968). Étude de la nourriture des Acridiens de la savane de Lamto en Côte d'Ivoire. Ann. Univ. Abidgan 1, 199-206.

Iannuzzi, R., and Labandeira, C. C. (2008). The oldest record of external foliage feeding and the expansion of insect folivory on land. Ann. Entomol. Soc. Am. 101, 79-94.

Isaias, R. M. S., Carneiro, R. G. S., Santos, J. C., and Oliveira, D. C. (2014). "Gall morphotypes in the Neotropics and the need to standardize them," in Neotropical Insect Galls, eds G. W. Fernandes, and J. C. Santos (Springer: Dordrecht), 51-67.

Jablonski, D. (2002). Survival without recovery after mass extinctions. Proc. Natl. Acad. Sci. U.S.A. 99, 8139-8144. doi: 10.1073/pnas.102163299

Jennings, J. R. (1974). Lower Pennsylvanian plants of Illinois. 1. A flora from the Pounds Sandstone Member of the Caseyville Formation. J. Paleontol. 48, 459-473.

Jeppson, L. R., Kiefer, H. H., and Baker, E. W. (1975). Mites Injurious to Economic Plants. Los Angeles, CA: University of California Press.

Jones, T. H. (1918). Life history of Pemphigus populi-transversus. J. Agric. Res. 14, 577-594.

Joseph, M. B., Gentles, M., and Pearse, I. S. (2011). The parasitoid community of Andricus quercuscalifornicus and its association with gall size, phenology, and location. Biodivers. Conserv. 20, 203-216. doi: 10.1007/s10531-010-9956-0

Kevan, P. G., Chaloner, W. G., and Savile, D. B. O. (1975). Interrelationships of early terrestrial arthropods and plants. Palaeontology 18, 391-417.

Kiefer, H. H., Baker, E. W., Kono, T., Delfinado, M., and Styer, W. E. (1982). An illustrated guide to plant abnormalities caused by eriophyid mites in North America. U. S. Dept. Agric., Agric. Hb. 573, 1-178.

Kim, W., Yukawa, J., Harris, K. M., Minami, T., Matsuo, K., and Skrzypczyńska, M. (2014). Description, host range and distribution of a new Macrodiplosis species (Diptera: Cecidomyiidae) that induces leaf-margin fold galls on deciduous Quercus (Fagaceae) with comparative notes on Palearctic congeners. Zootaxa 3821, 222-238. doi: 10.11646/zootaxa.3821.2.3
Kinsey, A. C. (1919). Fossil Cynipidae. Psyche 26, 44-49. doi: 10.1155/1919/96156 Kinsey, A. C. (1922). The gall wasp genus Neuroterus (Hymenoptera). India. Univ. Stud. 58, 1-150.

Knor, S., Prokop, J., Kvaček Janovský, Z., and Wappler, T. (2012). Plantarthropod associations from the Early Miocene of the Most Basin in North Bohemia-Palaeoecological and palaeoclimatological implications. Palaeogeogr. Palaeoclim. Palaeoecol. 321-322, 102-112. doi: 10.1016/j.palaeo. 2012.01.023

Knor, S., Skuhravá, M., Wappler, T., and Prokop, J. (2013). Galls and gall makers on plant leaves from the lower Miocene (Burdigalian) of the Czech Republic: Systematic and palaeoecological implications. Rev. Palaeobot. Palynol. 188, 38-51. doi: 10.1016/j.revpalbo.2012.10.001

Kodrul, T. M., Maslova, N. P., Vasilenko, D. V., Herman, A. B., Xu, Q., Jin, J., et al. (2018). A preliminary assessment of plant-biotic interactions in the Eocene of South China: evidence from Liquidambar L. (Saxifragales: Altingiaceae). Palaeogeogr. Palaeoclim. Palaeoecol. 492, 147-160. doi: 10.1016/j.palaeo.2017. 12.020

Krantz, G. W., and Lindquist, E. E. (1979). Evolution of phytophagous mites (Acari). Annu. Rev. Entomol. 24, 121-158. doi: 10.1146/annurev.en.24.010179. 001005

Krassilov, V. A. (2007). Mines and galls on fossil leaves from the Late Cretaceous of southern Negev, Israel. Afr. Invert. 48, 13-22.

Krassilov, V. A. (2008). Mine and gall predation as top down regulation in the plant-insect systems from the Cretaceous of Negev. Israel. Palaeogeogr. Palaeoclim. Palaeoecol. 261, 261-269. doi: 10.1016/j.palaeo.2008.01.017

Krassilov, V. A., and Karasev, E. (2008). First evidence of plant-arthropod interaction at the Permian-Triassic boundary in the Volga Basin, European Russia. Alavesia 2, 247-252.

Krassilov, V. A., and Shuklina, S. (2008). Arthropod trace diversity on fossil leaves from the mid-Cretaceous of Negev. Israel. Alavesia 2, 239-245.

Krassilov, V. A., Silantieva, N., and Lewy, Z. (2008). "Traumas on fossil leaves from the Cretaceous of Israel," in Plant-Arthropod Interactions in the Early Angiosperm History: Evidence from the Cretaceous of Israel, eds V. Krassilov and A. P. Rasnitsyn (Boston, MA: Pensoft and Brill), 7-187.

Kraus, J. E., Montenegro, G., and Kim, A. G. (1993). Morphological studies on entomogenous stem galls of Microgramma squamulosa (Kauf.) Sota (Polypodiaceae). Amer. Fern J. 83, 120-128. doi: 10.2307/1547588

Kunzmann, L., Moraweck, K., Müller, C., Schröder, I., Wappler, T., Grein, M., et al. (2019). A Paleogene leaf flora (Profen, Sachsen-Anhalt, Germany) and its potentials for palaeoecological and palaeoclimate reconstructions. Flora 254, 71-87. doi: 10.1016/j.flora.2018.11.005

Kustatscher, E., van Konijnenburg-van Cittert, J. H. A., Looy, C. V., Labandeira, C. C., Wappler, T., Butzmann, R., et al. (2017). The Lopingian (late Permian) flora from the Bletterbach Gorge in the Dolomites, Northern Italy: a review. GeoAlp 14, 39-61.

Labandeira, C. C. (2001). "The rise and diversification of insects," in Palaeobiology II, eds D. E. G. Briggs and P. R. Crowther (London: Blackwell), 82-88. doi: 10.1002/9780470999295.ch17

Labandeira, C. C. (2002). Paleobiology of middle Eocene plant-insect associations from the Pacific Northwest: a preliminary report. Rocky Mtn. Geol. 37, 31-59. doi: 10.2113/gsrocky.37.1.31

Labandeira, C. C. (2005). "Fossil history and evolutionary ecology of Diptera and their associations with plants," in The Evolutionary Biology of Flies, eds D. K. Yeates and B. M. Wiegmann (New York, NY: Columbia University Press), 217-273.

Labandeira, C. C. (2006a). The four phases of plant-arthropod associations in deep time. Geol. Acta 4, 409-438.

Labandeira, C. C. (2006b). Silurian to Triassic plant and hexapod clades and their associations: new data, a review, and interpretations. Arthro. Syst. Phylo. 64, 53-94.

Labandeira, C. C. (2007a). The origin of herbivory on land: Initial patterns of plant tissue consumption by arthropods. Ins. Sci. 14, 259-275. doi: 10.1111/j.17447917.2007.00152.x

Labandeira, C. C. (2007b). Assessing the fossil record of plant-insect interactions: ichnodata versus body-fossil data. SEPM Spe. Publ. 88, 9-26.

Labandeira, C. C. (2011). Paleobiological evidence for an earliest Late Carboniferous divergence time for major clades of Holometabola. Entomol. Am. 117, 9-21. doi: 10.1664/10-ra-011.1 
Labandeira, C. C. (2013a). A paleobiologic perspective on plant-insect interactions. Curr. Opin. Pl. Biol. 16, 414-421. doi: 10.1016/j.pbi.2013. 06.003

Labandeira, C. C. (2013b). Deep-time patterns of tissue consumption by terrestrial arthropod herbivores. Naturwissenschaften 100, 355-364. doi: 10.1007/s00114013-1035-4

Labandeira, C. C. (2014). "Why did terrestrial insect diversity not increase during the angiosperm radiation? Mid-Mesozoic plant-associated insect lineages harbor clues," in Evolutionary Biology: Genome Evolution, Speciation, Coevolution and Origin of Life, ed. P. Pontarotti (Cham: Springer International Publishing), 261-299. doi: 10.1007/978-3-319-07623-2_13

Labandeira, C. C., and Li, L. (2021). The history of insect parasitism and the MidMesozoic Parasitoid Revolution. Topics Geobiol. 49, 377-533. doi: 10.1007/9783-030-42484-8_11

Labandeira, C. C., and Allen, E. G. (2007). Minimal insect herbivory for the Lower Permian Coprolite Bone Bed site of north-central Texas USA, and comparison to other Late Paleozoic floras. Palaeogeogr. Palaeoclim., Palaeoecol. 247, 197-219.

Labandeira, C. C., and Currano, E. D. (2013). The fossil record of plant-insect dynamics. Annu. Rev. Earth Planet. Sci. 41, 287-311. doi: 10.1146/annurevearth-050212-124139

Labandeira, C. C., and Dunne, J. A. (2014). Data from: highly resolved early Eocene food webs show development of modern trophic structure after the end-Cretaceous extinction. Dryad Digital Repository doi: 10.10.5061/dryad. psofo

Labandeira, C. C., and Phillips, T. L. (1996). A Carboniferous petiole gall: insight into early ecologic history of the Holometabola. Proc. Natl. Acad. Sci. U.S.A. 93, 8470-8474.

Labandeira, C. C., and Phillips, T. L. (2002). Stem borings and petiole galls from Pennsylvanian tree ferns of Illinois, USA: implications for the origin of the borer and galler functional-feeding-groups and holometabolous insects. Palaeontograph. Abt. A Paläontol. 264, 1846-1933.

Labandeira, C. C., and Sepkoski, J. J., Jr. (1993). Insect diversity in the fossil record. Science 261, 310-315.

Labandeira, C. C., Anderson, J. M., and Anderson, H. M. (2018). Expansion of arthropod herbivory in Late Triassic South Africa: The Molteno Biota, Aasvoëlberg 411 site and developmental biology of a gall. Topics Geobiol. 46, 623-719. doi: 10.1007/978-3-319-68009-5_14

Labandeira, C. C., Johnson, K. R., and Lang, P. (2002a). Preliminary assessment of insect herbivory across the Cretaceous-Tertiary boundary: major extinction and minimum rebound. Geol. Soc. Amer. Spec. Pap. 361, 297-327.

Labandeira, C. C., Johnson, K. R., and Wilf, P. (2002b). Impact of the terminal Cretaceous event on plant-insect associations. Proc. Natl. Acad. Sci. U.S.A. 99, 2061-2066. doi: 10.1073/pnas.042492999

Labandeira, C. C., Kustatscher, E., and Wappler, T. (2016a). Floral assemblages and patterns of insect herbivory during the Permian to Triassic of Northeastern Italy. PLoS One 11:e0165206.

Labandeira, C. C., Tovar, F. J. R., and Uchman, A. (2016b). The end-Cretaceous extinction and ecosystem change: an ichnologic approach. Top. Geobiol. 40, 265-300.

Labandeira, C. C., Tremblay, S. L., Bartowski, K. E., and Hernick, L. V. (2014). Middle Devonian liverwort herbivory and antiherbivore defense. New Phytol. 202, 247-258. doi: 10.1111/nph.12643

Labandeira, C. C., Wilf, P., Johnson, K. R., and Marsh, F. (2007). Guide to Insect (and Other) Damage Types on Compressed Plant Fossils. Third version. Washington, DC: Smithsonian Institution.

Lamb, K. P. (1952). New plant galls: $1-$ mite and insect galls. Trans. Roy. Soc. N. Z. $79,349-362$.

Larew, H. G. (1982). A Comparative Anatomical Study of Galls Caused by the Major Cecidogenetic Groups, with Special Emphasis on the Nutritive Tissue. Ph.D. Thesis. Corvallis: Oregon State University.

Larew, H. G. (1986). The fossil gall record: a brief summary. Proc. Entomol. Soc. Wash. 88, 385-387.

Larew, H. G. (1992). “Fossil galls," in Biology of Insect-Induced Galls, eds J. D. Shorthouse and O. Rohfritsch (New York, NY: Oxford University Press), 51-59.

Lauriault, L. M., Thompson, D. C., Pierce, J. B., Bennett, A. B., Schutte, B. J., Beck, L. L., et al. (2004). Managing Aceria malherbae gall mites for control of field bindweed. New Mexico St. Univ. Ext. Serv. Circ. 600, 1-8.
Leckey, E. H., and Smith, D. M. (2015). Host fidelity over geologic time: restricted use of oaks by oak gallwasps. J. Paleontol. 89, 236-244. doi: 10.1017/jpa.2014.19 Leckey, E. H., and Smith, D. M. (2017). Individual host taxa may resist the climatemediated trend in herbivory: Cenozoic herbivory patterns in western North American oaks. Palaeogeogr. Palaeoclim. Palaeoecol. 487, 15-24. doi: 10.1016/j. palaeo.2017.08.003

Lee, G.-A., Davis, A. M., Smith, D. G., and McAndrews, J. H. (2004). Identifying fossil wild rice (Zizania) pollen from Cootes Paradise, Ontario: a new approach using scanning electron microscopy. J. Achaeol. Sci. 31, 411-421. doi: 10.1016/ j.jas.2003.09.009

Lewis, S. E. (1985). "Miocene insects from the Clarkia deposits of northern Idaho," in Late Cenozoic History on the Pacific Northwest, ed. C. Smiley (Washington, DC: American Association for the Advancement of Science), 245-264.

Li, H. Q. (2005). Early Cretaceous sarraceniacean-like pitcher plants from China. Acta Bot. Gallica 152, 227-234. doi: 10.1080/12538078.2005.1051 5473

Liu, H.-Y., Wei, H.-B., Chen, J., Guo, Y., Zhou, Y., Gou, X.-G., et al. (2020). A latitudinal gradient of plant-insect interactions during the late Permian in terrestrial ecosystems? New evidence from Southwest China. Glob. Planet. Ch. 192:103248. doi: 10.1016/j.gloplacha.2020.10 3248

Liu, Z., Engel, M. S., and Grimaldi, D. A. (2007). Phylogeny and geological history of the cynipoid wasps (Hymenoptera: Cynipoidea). Am. Mus. Novit. 3583, 1-48. doi: 10.1206/0003-0082(2007)3583[1:paghot]2.0.co;2

Looy, C. V. (2020). Voltzian conifers of the South Ash Pasture flora (Guadalupian, Texas): Johniphyllum multinerve gen. et sp. nov., Pseudovoltzia sapflorensis sp. nov., and Wantus acaulis sp. nov. Int. J. Plant Sci. 181, 363-385. doi: 10.1086/ 706853

Luginbill, P., and Urbahns, T. D. (1916). The spike-horned leaf miner, an enemy of grains and grasses. U. S. Dept. Agric. Bull. 432, $1-18$.

Ma, F.-J., Ling, C.-C., Meng-Sha, O.-Y., Yang, G.-M., Shen, X.-P., and Wang, Q.-J. (2020). Plant-insect interactions from the Miocene (Burdigalian-Langhian) of Jiangxi, China. Rev. Palaeobot. Palynol. 275, 104176. doi: 10.1016/j.revpalbo. 2020.104176

Maccracken, S. A., and Labandeira, C. C. (2020). The Middle Permian South Ash Pasture assemblage of north-central Texas: coniferophyte and gigantopterid herbivory and longer-term herbivory trends. Int. J. Plant Sci. 181, 342-362. doi: 10.1086/706852

Maccracken, S. A., Sohn, J.-C., Miller, I. M., and Labandeira, C. C. (2021). A new Late Cretaceous leaf mine Leucopteropsa spiralae gen. et sp. nov. (Lepidoptera: Lyonetiidae) represents the first confirmed fossil evidence of the Cemiostominae. J. Syst. Palaeont. 19, 131-144. doi: 10.1080/14772019.2021. 1881177

Mädler, K. (1936). Eine blattgalle an einem vorweltlichen pappel-blatt. Natur Volk $66,271-274$.

Maia, V. C., and Fernandes, G. W. (2004). Insect galls from Serra de São José (Tiradentes, MG, Brazil). Bras. J. Biol. 64, 423-445. doi: 10.1590/s151969842004000300007

Maia, V. C., and Santos, M. G. (2011). A new genus and species of gall midge (Diptera, Cecidomyiidae) associated with Microgramma vaccinifolia (Langsd. \& Fisch.) Copel. (Polypodiaceae) from Brazil. Rev. Bras. Entomol. 55, 40-44. doi: 10.1590/s0085-56262011000100008

Mamay, S. H. (1960). Padgettia, a new genus based on fertile neuropteroid foliage from the Permian of Texas. Palaeobotanist 9, 53-57. doi: 10.1017/ s0022336000038944

Mani, M. S. (1964). Ecology of Plant Galls. Hague: W. Junk.

Mani, M. S. (1992). "Introduction to cecidology," in Biology of Insect-Induced Galls, eds J. D. Shorthouse and O. Rohfritsch (New York, NY: Oxford University Press), 3-7.

Martin, N. A. (2007). Ecological observations on grass leaf mining flies in New Zealand. N. Z. Entomol. 30, 35-39. doi: 10.1080/00779962.2007.9722149

Maslova, N. P., Vasilenko, D. V., and Kodrul, T. M. (2016). Phytopathology in fossil plants: New data, questions of classification. Paleontol. J. 50, 202-208. doi: 10.1134/s0031030116020040

McElwain, J. C., and Punyasena, S. W. (2007). Mass extinction events and the plant fossil record. Tr. Ecol. Evol 22, 548-557. doi: 10.1016/j.tree.2007.09.003 
McLeish, M. J., Chapman, T. W., and Mound, L. A. (2006). Gall morphotype corresponds to separate species of gall-inducing thrips (Thysanoptera: Phlaeothripidae). Biol. J. Linn. Soc. 88, 555-563. doi: 10.1111/j.1095-8312.2006. 00641.x

McLeish, M. J., Chapman, T. W., and Schwarz, M. P. (2007). Host-driven diversification of gall-inducing Acacia thrips and the aridification of Australia. BMC Biol. 5:3. doi: 10.1186/1741-7007-5-3

McLoughlin, S. (2011). New records of leaf galls and arthropod oviposition scars in Permian-Triassic Gondwanan gymnosperms. Austral. J. Bot. 59, 156-169. doi: 10.1071/bt10297

McLoughlin, S., Martin, S. K., and Beattie, R. (2015). The record of Australian Jurassic plant-arthropod interactions. Gond. Res. 27, 940-959. doi: 10.1016/ j.gr.2013.11.009

Mehotra, R. C., Dilcher, D. L., and Awasthi, N. (1998). A Paleocene Mangifera-like leaf fossil from India. Phytomorphology 48, 91-100.

Mei, M.-t., Dilcher, D. L., and Wan, Z.-h. (1992). A new seed-bearing leaf from the Permian of China. Palaeobotanist 41, 98-109.

Meyer, J. (1969). Irrigation vasculaire dans les galles. Bull. Soc. Bot. France 116(Suppl.), 75-97. doi: 10.1080/00378941.1969.10838711

Meyer, J. (1987). Plant Galls and Gall Inducers. Stuttgart: Gebrüder Borntraeger.

Miki, S. (1937). Plant fossils from the Stegodon Beds and the Elephas Beds near Asashi. Jap. J. Bot. 8, 303-341.

Miller, D. G. III, and Raman, A. (2019). Host-plant relations of gall-inducing insects. Ann. Entomol. Soc. Amer. 112, 1-19. doi: 10.1093/aesa/say034

Miller, D. R., and Davidson, J. A. (2005). Armored Scale Pests of Trees and Shrubs. Ithaca, NY: Cornell University Press.

Miller, S. E. (1997). Late Quaternary insects of Rancho La Brea, California, USA. Quat. Proc. 5, 185-191.

Minter, N. J., Buatois, L. A., Mángano, M. G., Davies, N. S., Gibling, M. R., and Labandeira, C. (2016). The establishment of continental ecosystems. Top. Geobiol. 39, 205-324.

Möhn, E. (1960). Eine neue Gallmücke aus der niederrheinischen Braunkohle, Sequoiomyia kraeuseli n. g., n. sp. (Diptera, Itonididae). Senck. Leth. 41, 513522.

Möller, A. L., Kaulfuss, U., Lee, D. E., and Wappler, T. (2019). High richness of insect herbivory from the early Miocene Hindon Maar crater, Otago, New Zealand. PeerJ 5:e2985. doi: 10.7717/peerj.2985

Moore, D., and Clements, R. O. (1985). Patterns of infestation by stem-borers (Chloropidae and Opomyzidae) in grassland. Entomol. Exp. Appl. 37, 183-186. doi: 10.1111/j.1570-7458.1985.tb03471.x

Moran, N. A. (1989). A 48-million-year-old aphid-host plant association and complex life cycle: biogeographic evidence. Science 243, 173-175. doi: 10.1126/ science.245.4914.173

Mutun, S., and Dinç, S. (2019). The Anatolian diagonal and paleoclimatic changes shaped the phylogeography of Cynips quercus (Hymenoptera, Cynipidae). Ann. Zool. Fenn. 56, 65-83. doi: 10.5735/086.056.0107

Nagler, C., and Haug, J. T. (2015). From fossil parasitoids to vectors: insects as parasites and hosts. Adv. Parasitol. 90, 137-200. doi: 10.1016/bs.apar.2015.09. 003

Naranjo-Ortiz, M. A., and Gabaldón, T. (2019). Fungal evolution: major ecological adaptations and evolutionary transitions. Biol. Rev. 94, 1443-1476. doi: 10. $1111 /$ brv. 12510

Nartshuk, E. P. (2014). Grass-fly larvae (Diptera, Chloropidae): Diversity, habitats, and feeding specializations. Entomol. Rev. 94, 514-525. doi: 10.1134/ s001387381404006x

Nel, A., and Prokop, J. (2006). New fossil gall midges from the earliest Eocene French amber (Insecta, Diptera, Cecidomyiidae). Geodiversitas 28, 37-54.

Nishida, H., and Hayashi, N. (1996). Cretaceous coleopteran larva fed on a female fructification of an extinct gymnosperm. J. Pl. Res. 109, 327-330. doi: 10.1007/ bf02344479

Nyman, T. (2000). Evolution of gall morphology and host-plant relationships in willow-feeding sawflies (Hymenoptera: Tenthredinidae). Evolution 54, 526533. doi: 10.1111/j.0014-3820.2000.tb00055.x

Odum, E. P. (1968). Energy flow in ecosystems: a historical review. Am. Zool. 8, 11-18. doi: 10.1093/icb/8.1.11

Payros, A., Ortíz, S., Millán, I., Arostegi, J., Orue-Etxebarria, X., and Apellaniz, E. (2015). Early Eocene climatic optimum: Environmental impact on the North
Iberian continental margin. Geol. Soc. Am. Bull. 127, 1632-1644. doi: 10.1130/ b31278.1

Peris, D., Labandeira, C. C., Barrón Delclòs, X., Rust, J., and Wang, B. (2020). Generalist pollen-feeding beetles during the mid-Cretaceous. iScience 23:100913. doi: 10.1016/j.isci.2020.100913

Perkovsky, E. E., and Fedotova, Z. A. (2004). New species of gall midges (Diptera, Cecidomyiidae) from Rovno Amber: Subfamily Lestremiinae, tribes Micromyiini and Peromyiini. Paleontol. J. 38, 396-406.

Perkovsky, E. E., and Fedotova, Z. A. (2008). New gall midge taxa of the subfamilies Porricondylinae and Lasiopterinae (Diptera, Cecidomyiidae) from the Rovno Amber. Paleontol. J. 42, 166-175.

Pinheiro, E. R. S., Iannuzzi, R., and Duarte, L. O. S. (2016). Insect herbivory fluctuates through geological time. Ecology 97, 2501-2510. doi: 10.1002/ecy. 1476

Pinheiro, E. R. S., Tybusch, G. P., and Iannuzzi, R. (2012). New evidence of plant-insect interactions in the Lower Permian from Western Gondwana. Palaeobotanist 61, 67-74.

Piperno, D. R., and Pearsall, D. M. (1998). The silica bodies of tropical American grasses: morphology, taxonomy, and implications for grass systematics and fossil phytolith identification. Smithson. Contr. Bot. 85, 1-40. doi: 10.5479/si. $0081024 x .85$

Plumb, G. H. (1953). The formation and development of the Norway spruce gall caused by Adelges abietis L. Connecticut Agr. Expt. Sta. Bull. 566, $1-77$.

Plumstead, D. P. (1963). The influence of plants and environment on the developing animal life of Karoo times. So. Afr. J. Sci. 59, 147-152.

Prasad, V., Strömberg, C. A. E., Alimohammadian, H., and Sahni, A. (2005). Dinosaur coprolites and the early evolution of grasses and grazers. Science 310, 1177-1180. doi: 10.1126/science.1118806

Prevec, R., Labandeira, C. C., Neveling, J., Gastaldo, R. A., Looy, C. V., and Bamford, M. (2009). Portrait of a Gondwanan ecosystem: a new late Permian fossil locality from KwaZulu-Natal, South Africa. Rev. Palaeobot. Palynol. 156, 454-493. doi: 10.1016/j.revpalbo.2009.04.012

Price, P. W. (2003). Macroevolutionary Theory on Macroecological Patterns. Cambridge: Cambridge University Press.

Price, P. W., Fernandes, G. W., and Waring, G. L. (1987). Adaptive nature of insect galls. Environ. Entomol. 16, 15-24. doi: 10.1093/ee/16.1.15

Prinzing, A., Ozinga, W. A., Brandle, M., Courty, P. M., Hennion, F., Labandeira, C., et al. (2016). Benefits from living together? Clades whose species use similar habitats may persist as a result of eco-evolutionary feedbacks. New Phytol. 213, 66-82. doi: 10.1111/nph.14341

Quinn, M. A., and Walgenbach, D. D. (1990). Influence of grazing history on the community structure of grasshoppers of a mixedgrass prairie. Environ. Entomol. 19, 1756-1766. doi: 10.1093/ee/19. 6.1756

Raman, A. (2007). Insect-induced plant galls of India: unresolved questions. Curr. Sci. 92, 748-757.

Raman, A. (2012). Gall induction by hemipteroid insects. J. Plant Interact. 7, 29-44. doi: 10.1080/17429145.2011.630847

Raman, A., Burckhardt, D., and Harris, K. M. (2009). Biology and adaptive radiation in the gall-inducing Cecidomyiidae (Insecta Diptera) and Calophyidae (Insecta Hemiptera) on Mangifera indica (Anacardiaceae) in the Indian subcontinent. Trop. Zool. 22, 27-56. doi: 10.1080/00305316.2007.10417497

Raman, A., Schaefer, C. W., and Withers, T. M. (2005). "Galls and gall-inducing arthropods: an overview of their biology, ecology, and evolution", in Biology, Ecology, and Evolution of Gall-Inducing Arthropods, eds (A. Raman, C. W. Schaefer, and T. M. Withers (Enfield, NH: Science Publishers), 1-33.

Redfern, M. (2011). Plant Galls. London: HarperCollins.

Redfern, M., Shirley, P., and Bloxham, M. (2002). British Plant Galls: Identification of Galls on Plants and Fungi. Shrewsbury: FSC Publications.

Ribeiro, S. P., Basset, Y., and Kitching, R. (2014). "Density of insect galls in the forest understorey and canopy: Neotropical, Gondwana or global patterns?, in Neotropical Insect Galls, eds G. W. Fernandes and J. C. Santos (Dordrecht: Springer).

Ride, W. D. L., Sabrosky, C. W., Bernard, G., and Melville, R. V. (eds). (1985). Code International de Nomenclature Zoologique Adopteé par la XX Assemblé Générale de l'Union Internationale des Sciences Biologiques, 3rd Edn. London: 
International Trust for Zoological Nomenclature and the British Museum of Natural History.

Rindsberg, A. K. (1990). Ichnological consequences of the 1985 International Code of Zoological Nomenclature. Ichnos 1, 59-63. doi: 10.1080/10420949009386333

Robinson, M. A. (1980). Archaeological finds of wasp galls. J. Archaeol. Sci. 7, 93-95. doi: 10.1016/s0305-4403(80)80009-4

Robledo, J. M., Pinheiro, E. R. S., Gnaedinger, S. C., and Wappler, T. (2018). Plantinsect interactions on dicots and ferns from the Miocene of Argentina. Palaios 33, 338-352. doi: 10.2110/palo.2017.100

Robledo, J. M., Sarzetti, L. C., and Anzótegui, L. M. (2015). Phytophagy on fossil ferns from Argentina (Palo Pintado Formation, late Miocene): a review of their fossil record and ichnotaxonomy. Rev. Bras. Paleontol. 18, 225-238. doi: 10.4072/rbp.2015.2.04

Rohfritsch, O. (1987). "Different food supply strategies in midge induced plant galls," in Insect-Plants: Proceedings of the $6^{\text {th }}$ International Symposium on Insect-Plant Relationships (PAU 1986), eds V. Labeyrie, G. Fabries, and D. Lachaise (Dordrecht: W. Junk Publishers), 195-200.

Rohfritsch, O. (1992). "Patterns in gall development," in Biology of Insect-Induced Galls, eds J. D. Shorthouse and O. Rohfritsch (Oxford: Oxford University Press), 60-86.

Röhl, U., Bralower, T. J., Norris, R. D., and Wefer, G. (2000). New chronology for the Late Paleocene Thermal Maximum and its environmental implications. Geology 28, 927-930. doi: 10.1130/0091-7613(2000)028<0927:ncftlp > 2.3.co;2

Rokas, A., Nylander, J. A. A., Ronquist, F., and Stone, G. H. (2001). A maximumlikelihood analysis of eight phylogenetic markers in gallwasps (Hymenoptera: Cynipidae): Implications for insect phylogenetic studies. Mol. Phylo. Evol. 22, 206-219. doi: 10.1006/mpev.2001.1032

Romero, Q. Q., and Benson, W. W. (2005). Biotic interactions of mites, plants and leaf domatia. Curr. Opin. Plant Biol. 8, 436-440. doi: 10.1016/j.pbi.2005.05.006

Ronquist, F., and Liljeblad, J. (2001). Evolution of the gall wasp-host plant association. Evolution 55, 2503-2522. doi: 10.1111/j.0014-3820.2001.tb00765.x

Ronquist, F., Nieves-Aldrey, J.-L., Buffington, M. L., Liu, Z., Liljeblad, J., and Nylander, J. A. A. (2015). Phylogeny, evolution and classification of gall wasps: the plot thickens. PLoS One 10:e0123301. doi: 10.1371/journal.pone.0123301

Rosenthal, S. S., and Koehler, C. S. (1971). Heterogony in some gall-forming Cynipidae (Hymenoptera) with notes on the biology of Neuroterus saltatorius. Ann. Entomol. Soc. Am. 64, 565-570. doi: 10.1093/aesa/64.3.565

Roskam, J. C. (1992). "Evolution of the gall-inducing guild," in Biology of InsectInduced Galls, eds J. D. Shorthouse and O. Rohfritsch (New York, NY: Oxford University Press), 34-49.

Ross, H. (1932). Prakitikum der Gallenkunde (Cecidologie), Entstchung, Entwicklung, Bau der Durch Tiere und Pflanze Hervorgerufenen Gallenbildungen Sowie Ökologie der Gallenerreger. Berlin: Julius Springer.

Rübsaamen, E. H. (1929). "Gallbildungen," in Handbuch der Entomologie, Band II, ed. C. Schröder (Jena: Gustav Fischer), 219-248.

Russo, R. (2006). A Field Guide to Plant Galls of California and Other Western States. Los Angeles, CA: University of California Press.

Sahni, M. (1948). The Pentoxyleae: a new group of Jurassic gymnosperms from the Rajmahal Hills of India. Bot. Gaz. 110, 47-80. doi: 10.1086/335517

Sato, S., and Yukawa, J. (2001). Absence record of Fagus gall midges (Diptera: Cecidomyiidae) on Ulleung Island, Korea and in North America. Esakia 41, $17-25$.

Schachat, S., and Labandeira, C. C. (2015). Evolution of a complex behavior: the origin and initial diversification of foliar galling by Permian insects. Sci. Nat. 102:14. doi: 10.1007/s00114-015-1266-7

Schachat, S., and Labandeira, C. C. (2021). Are insects heading toward their first mass extinction? Distinguishing turnover from crises in their fossil record. Ann. Entomol. Soc. Am. 114, 99-118.

Schachat, S., Labandeira, C. C., and Chaney, D. S. (2015). Insect herbivory from early Permian Mitchell Creek Flats of north-central Texas: opportunism in a balanced component community. Palaeogeogr. Palaeoclim. Palaeoecol. 440, 830-847.

Schachat, S., Labandeira, C. C., Clapham, M. E., and Payne, J. L. (2019). A Cretaceous peak in family-level insect diversity estimated with mark-recapture methodology. Proc. R. Soc. B 286:0192054.

Schachat, S., Labandeira, C. C., Gordon, J., Chaney, D. S., Levi, S., Halthore, M. N., et al. (2014). Plant-insect interactions from early Permian (Kungurian) Colwell Creek Pond, north-central Texas: The early spread of herbivory in riparian environments. Internat. J. Plant Sci. 175, 855-890.

Schachat, S., Maccracken, S. A., and Labandeira, C. C. (2020). Sampling fossil floras for the study of insect herbivory: how many leaves is enough? Foss. Rec. 23, 15-32. doi: 10.5194/fr-23-15-2020

Schaefer, C. W., Raman, A., and Withers, T. M. (2005). "Galls and gallinducing arthropods: ecological issues and evolutionary problems," in Biology, Ecology and Evolution of Gall-inducing Arthropods, eds A. Raman, C. W. Schaefer, and C. W. Withers (Enfield, NH: Science Publishers), 761-766.

Scheirs, J., De Bruyn, L., and Verhagen, R. (2001). Nutritional benefits of the leafmining behaviour of two grass miners: a test of the selective feeding hypothesis. Ecol. Entomol. 26, 509-516. doi: 10.1046/j.1365-2311.2001.00356.x

Schmidt, L. E. A., Dunn, R. E., Mercer, J., Dechesne, M., and Currano, E. D. (2019). Plant and insect herbivore community variation across the PaleoceneEocene boundary in the Hanna Basin, southeastern Wyoming. PeerJ 7:e7798. doi: $10.7717 /$ peerj.7798

Scott, A. C., and Taylor, T. N. (1983). Plant/animal interactions during the Upper Carboniferous. Bot. Rev. 49, 259-307. doi: 10.1007/bf02861089

Scott, A. C., Anderson, J. M., and Anderson, H. M. (2004). Evidence of plant-insect interactions in the Upper Triassic Molteno Formation of South Africa. J. Geol. Soc. Lond. 161, 401-410. doi: 10.1144/0016-764903-118

Scott, A. C., Stephenson, J., and Chaloner, W. G. (1992). Interaction and coevolution of plants and arthropods during the Palaeozoic and Mesozoic. Phil. Trans. R. Soc. Lond. 335, 129-165. doi: 10.1098/rstb.1992.0016

Scott, A. C., Stephenson, J., and Collinson, M. E. (1994). The fossil record of leaves with galls. Syst. Assn. Spec. Vol. 49, 447-470.

Selden, P., and Nudds, J. C. (2012). Evolution of Fossil Ecosystems, 2 Edn. London: Academic Press.

Shcherbakov, D. E. (2000). Permian faunas of Homoptera (Hemiptera) in relation to phytogeography and the Permo-Triassic Crisis. Paleontol. J. 34, S251-S267.

Shcherbakov, D. E. (2008a). Insect recovery after the Permian/Triassic crisis. Alavesia 2, 125-131.

Shcherbakov, D. E. (2008b). On Permian and Triassic insect faunas in relation to biogeography and the Permian-Triassic crisis. Paleontol. J. 42, 15-31.

Sidorchuk, E. A., Schmidt, A. R., Ragazzi, E., Roghi, G., and Lindquist, E. E. (2015). Plant-feeding mite diversity in Triassic amber (Acari: Tetrapodili). J. Syst. Palaeontol. 13, 129-151. doi: 10.1080/14772019.2013.867373

Sinclair, R. J., and Hughes, L. (2008). Incidence of leaf mining in different vegetation types across rainfall, canopy cover and latitudinal gradients. Aust. Ecol. 33, 353-360. doi: 10.1111/j.1442-9993.2007.01825.x

Skuhravá, M., and Skuhravý, V. (2009). Species richness of gall midges (Diptera: Cecidomyiidae) in Europe (West Palaearctic): biogeography and coevolution with host plants. Acta Soc. Zool. Bohem. 73, 87-156.

Slater, B. J., McLoughlin, S., and Hilton, J. (2012). Animal-plant interactions in a Middle Permian permineralised peat of the Bainmedart Coal Measures, Prince Charles Mountains, Antarctica. Palaeogeogr. Palaeoclim. Palaeoecol. 363-364, 109-126. doi: 10.1016/j.palaeo.2012.08.018

Spencer, K. A. (1990). Host Specialization in the World Agromyzidae. Dordrecht: Kluwer.

Srivastava, A. K. (2007). Fossil evidences of gall-inducing arthropod-plant interactions in the Indian subcontinent. Orien. Ins. 41, 213-222. doi: 10.1080/ 00305316.2007.10417505

Srivastava, A. K., Abbas, S. R., Mehrotra, R. C., and Srivastava, R. (2000). Cecidomyiid leaf galls in Palaeocene leaves from north-eastern India. Acta Palaeobot 40, 43-47.

Srivastava, A. K., and Srivastava, G. P. (2016). Insect herbivory in Gondwana plants. Palaeobotanist 65, 131-137.

Stephenson, J. (1991). Evidence of Plant/Insect Interactions in the Late Cretaceous and Early Tertiary. Ph.D. thesis. London: University of London.

Stern, D. L. (1995). Phylogenetic evidence that aphids, rather than plants, determine gall morphology. Proc. Roy. Soc. Lond. B 256, 203-209.

Stiling, P. D., and Strong, D. R. (1983). Weak competition among Spartina stem borers, by means of murder. Ecology 64, 770-778. doi: 10.2307/1937200

Stone, G. N., and Schönrogge, K. (2003). The adaptive significance of insect gall morphology. Tr. Ecol. Evol. 18, 512-522. doi: 10.1016/s0169-5347(03)00247-7

Stone, G. N., Hernandez-Lopez, A., Nicholls, J. A., Pierro, E., di Pujade-Villar, J., Melika, G., et al. (2009). Extreme host plant conservatism during at least 20 
million years of host plant pursuit by oak gallwasps. Evolution 63, 854-869. doi: 10.1111/j.1558-5646.2008.00604.x

Stone, G. N., van der Ham, R. W. J. M., and Brewer, J. G. (2008). Fossil oak galls preserve ancient multitrophic interactions. Proc. Roy. Soc. B (Biol. Sci.) 275, 2213-2219. doi: 10.1098/rspb.2008.0494

Straus, A. (1977). Gallen, Minen und andere Fraßspuren im Pliokän von Willershausem am Harz. Verhandl. Bot. Vereins Prov. Brandenburg 113, 43-80.

Stull, G. W., Labandeira, C. C., DiMichele, W. A., and Chaney, D. S. (2013). The "seeds" on Padgettia readi are insect galls: reassignment of the plant to Odontopteris, the gall to Ovofoligallites n. gen., and the evolutionary implications thereof. J. Paleontol. 87, 217-231.

Su, T., Adams, J. M., Wappler, T., Huang, Y.-J., Jacques, F. M. B., Liu, Y.-S., et al. (2015). Resilience of plant-insect interactions in an oak lineage through Quaternary climate change. Paleobiology 41, 174-186. doi: 10.1017/pab.2014.11

Thomas, B. A. (1969). A new British Carboniferous calamite cone, Paracalamostachys spadiciformis. Palaeontology 12, 253-261.

Thomasson, J. R. (1982). Fossil grass anthoecia and other plant fossils from arthropod burrows in the Miocene of western Nebraska. J. Paleontol. 56, 1011-1017.

Tscharntke, T. (1988). Variability in the grass Phragmites australis in relation to the behaviour and mortality of the gall-inducing midge Giraudiella inclusa (Dipt., Cecidomyiidae). Oecologia 76, 504-512. doi: 10.1007/bf0039 7861

Tscharntke, T. (1989). Attack by a stem-boring moth increases susceptibility of Phragmites australis to gall-making by a midge: mechanisms and effects on midge population dynamics. Oikos 55, 93-100. doi: 10.2307/3565878

Tscharntke, T. (1994). "Tritrophic interactions in gallmaker communities on Phragmites australis: testing ecological hypotheses," in Gall-Forming Insects: Ecology, Physiology and Evolution, eds Y. Baranchikov, W. J. Mattson, and P. W. Price (St. Paul, MN: U.S.D.A. Gen. Publ. No. Cent. For. Expt. Sta), 73-92.

Tscharntke, T., and Greiler, H.-J. (1995). Insect communities, grasses, and grasslands. Annu. Rev. Entomol. 40, 535-558. doi: 10.1146/annurev.en.40. 010195.002535

Upchurch, G. R. Jr., and Dilcher, D. L. (1990). Cenomanian angiosperm leaf megafossil, Dakota Formation, Rose Creek Locality, Jefferson County, Southeastern Nebraska. U. S. Geol. Surv. Bull. 1915, 1-31.

Vasilenko, D. V. (2005). Damages on Mesozoic plants from the Transbaikalian locality Chernovskie Kopi. Paleontol. J. 39, 628-633.

Vasilenko, D. V. (2007). Feeding damage on Upper Permian plants from the Sukhona River. Paleontol. J. 41, 207-211. doi: 10.1134/s0031030107020116

Vasilenko, D. V., and Maslova, N. P. (2015). Columnar galls on Platimeliphyllum snatolense N. Maslova (Angiospermae) leaves from the upper Paleocene of western Kamchatka Peninsula. Paleontol. J. 49, 552-558. doi: 10.1134/ s0031030115050147

Vishniakova, V. N. (1981). New Palaeozoic and Mesozoic lophioneurids (Thripida, Lophioneuridae). Trans. Paleontol. Inst. 183, 43-63.

Vishnu-Mittre. (1957). Fossil galls on some Jurassic conifer leaves. Curr. Sci. 26, $210-211$.

Van Amerom, H. W. J. (1973). "Gibt es cecidien im karbon bei calamiten und asterophylliten?," in Herausgegeben vom Geologischen Landesamt NordrheinWestfalen, Krefeld, Vol. 2, ed. K.-H. Josten (Krefeld: van Acken), 2-7. doi: $10.1007 / \mathrm{s} 15033-021-2690-3$

Von Schlechtendal, D. H. R. (1916). Eriophyidocecidien - Die Durch Gallmilben Verurachten Pflanzengallen. Stuttgart: E. Schweizerbart'sche Verlagsbuchhandlung.

Waggoner, B. M. (1999). Fossil oak leaf galls from the Stinking Water paleoflora of Oregon (middle Miocene). PaleoBios 19, 8-14.

Waggoner, B. M., and Poteet, M. F. (1996). Unusual oak leaf galls from Middle Miocene of northwestern Nevada. J. Paleont. 70, 1080-1084.

Walker, J. D., Geissman, J. W., Bowring, S. A., and Babcock, L. E. (2018). Geologic time scale v. 5.0. Geol. Soc. Am. Bull. doi: 10.1130/2018.CTS005R3C

Wappler, T. (2010). Insect herbivory close to the Oligocene-Miocene transitionA quantitative analysis. Palaeogeogr. Palaeoclim. Palaeoecol. 292, 540-550. doi: 10.1016/j.palaeo.2010.04.029

Wappler, T., and Ben-Dov, Y. (2008). Preservation of armoured scale insects on angiosperm leaves from the Eocene of Germany. Acta Palaeontol. Pol. 53, 627-634. doi: 10.4202/app.2008.0407
Wappler, T., and Grímsson, F. (2016). Before the 'Big Chill': Patterns of plantinsect associations from the Neogene of Iceland. Glob. Planet. Ch. 142, 73-86. doi: 10.1016/j.gloplacha.2016.05.003

Wappler, T., Currano, E. D., Wilf, P., Rust, J., and Labandeira, C. C. (2009). No post-Cretaceous ecosystem depression in European forests? Rich insect-feeding damage on diverse middle Palaeocene plants, Menat, France. Proc. Roy. Soc. B (Biol. Sci.) 276, 4271-4277.

Wappler, T., Kustatscher, E., and Dellantonio, E. (2015). Plant-insect interactions from Middle Triassic (late Ladinian) of Monte Agnello (Dolomites, N-Italy) initial pattern and response to abiotic environmental perturbations. PeerJ 3:e921. doi: 10.7717/peerj.921

Wappler, T., Labandeira, C. C., Rust, J., Frankenhäuser, H., and Wilde, V. (2012). Testing for the effects and consequences of mid Paleogene climate change on insect herbivory. PLoS One 7:e40744. doi: 10.1371/journal.pone.0040744

Wappler, T., Tokuda, M., Yukawa, J., and Wilde, V. (2010). Insect herbivores on Laurophyllum lanigeroides (Engelhardt 1992) Wilde: a role of a distinct plantinsect associational suite in host taxonomic assignment. Palaeontogr. Abt. B (Palaeobot. Palaeophytol.) 283, 137-155. doi: 10.1127/palb/283/2010/137

Ward, L. K., Hackshaw, A., and Clarke, R. T. (2003). Do food-plant preferences of modern families of phytophagous insects and mites reflect past evolution with plants? Biol. J. Linn. Soc. 78, 51-83. doi: 10.1046/j.1095-8312.2003.00128.x

Ward, P., Labandeira, C., Laurin, M., and Berner, R. A. (2006). Confirmation of Romer's Gap as a low oxygen interval constraining the timing of initial arthropod and vertebrate terrestrialization. Proc. Natl. Acad. Sci. U.S.A. 103, 16818-16822. doi: 10.1073/pnas.0607824103

Weiss, C. E. (1876). Steinkohlen - calamitarien. Abhandl. Geol. Special. Preus. Thüring. Staat. 2, 1-19.

Weiss, F. E. (1904). A probable parasite of stigmarian rootlets. New Phytol. 3, 63-68. doi: 10.1111/j.1469-8137.1904.tb05844.x

Wells, B. W. (1916). The comparative morphology of the zoocecidia of Celtis occidentalis. Ohio J. Sci. 16, 12-19.

Westphal, E. (1992). "Cecidogenesis and resistance phenomena in mite-induced galls," in Biology of Insect-Induced Galls, eds J. D. Shorthouse and O. Rohfritsch (New York, NY: Oxford University Press), 141-156. doi: 10.3759/tropics.7.141

Wilf, P. (2008). Insect-damaged fossil leaves record food web response to ancient climate change and extinction. New Phytol. 178, 486-502. doi: 10.1111/j.14698137.2008.02395.x

Wilf, P., and Labandeira, C. C. (1999). Response of plant-insect associations to Paleocene-Eocene warming. Science 284, 2153-2156. doi: 10.1126/science.284. 5423.2153

Wilf, P., Labandeira, C. C., Johnson, K. R., and Cúneo, N. R. (2005). Richness of plant-insect associations in Eocene Patagonia: a legacy for South American biodiversity. Proc. Natl. Acad. Sci. U.S.A. 102, 8944-8948.

Wilf, P., Labandeira, C. C., Johnson, K. R., and Ellis, B. (2006). Decoupled plant and insect diversity after the end-Cretaceous extinction. Science 313, 1112-1115.

Wilf, P., Labandeira, C. C., Johnson, K. R., Coley, P. D., and Cutter, A. D. (2001). Insect herbivory, plant defense, and early Cenozoic climate change. Proc. Natl. Acad. Sci. U.S.A. 98, 6221-6226. doi: 10.1073/pnas.111069498

Wing, S. L., Herrera, F., Jaramillo, C. A., Gomez-Navarro, C., Wilf, P., and Labandeira, C. C. (2009). Late Paleocene fossils from the Cerrejon Formation, Colombia, are the earliest record of Neotropical rainforest. Proc. Natl. Acad. Sci. U.S.A. 100, 18627-18632.

Wittlake, E. B. (1969). Fossil phylloxerid plant galls from the lower Eocene. J. Arkansas Acad. Sci. 23, 164-167.

Wittlake, E. B. (1981). "Fossil plant galls," in Neoplasms-Comparative Pathology of Growth in Animals, Plants, and Man, ed. H. E. Kaiser (London: Williams \& Wilkins), 729-731.

Wong, H. R., Melvin, J. C. E., and Harper, A. N. (1977). Common insect and mite galls of the Canadian prairies. Canad. For. Serv. No. For. Res. Cent. Info. Rept. NOR-X 196, 1-81. doi: 10.1007/978-94-017-8783-3_1

Wong, W. O., Dilcher, D. L., Labandeira, C. C., Sun, G., and Fleischmann, A. (2015). Early Cretaceous Archaeamphora is not a carnivorous angiosperm. Front. Pl. Sci. 6:326. doi: 10.3389/fpls.2015. 00326

$\mathrm{Xu}$, Q., Jin, J., and Labandeira, C. C. (2018). Williamson Drive: herbivory from a north-central Texas flora of latest Pennsylvanian age shows discrete component community structure, expansion of piercing and sucking, and plant 
counterdefenses. Rev. Palaeobot. Palynol. 251, 28-72. doi: 10.1016/j.revpalbo. 2018.01.002

Yang, M.-M., and Mitter, C. (1993). Biosystematics of hackberry psyllids (Pachypsylla) and the evolution of gall and lerp formation in psyllids: a preliminary report. U. S. Dept. Agric. For. Serv. Gen. Tech. Rept. NC 174, 172-185.

Zachos, J. C., Röhl, U., Schellenberg, S. A., Sluijs, A., Hodell, D. A., Kelly, D. C., et al. (2003). Rapid acidification of the ocean during the Paleocene-Eocene Thermal Maximum. Science 308, 1611-1615. doi: 10.1126/science.1109004

Zerova, M. D. (1978). Fauna of the Ukraine: Eurytomidae, Vol. 11. Kiev: Akad. Nauk Ukrainskoj S.S.R.
Conflict of Interest: The author declares that the research was conducted in the absence of any commercial or financial relationships that could be construed as a potential conflict of interest.

Copyright (c) 2021 Labandeira. This is an open-access article distributed under the terms of the Creative Commons Attribution License (CC BY). The use, distribution or reproduction in other forums is permitted, provided the original author(s) and the copyright owner(s) are credited and that the original publication in this journal is cited, in accordance with accepted academic practice. No use, distribution or reproduction is permitted which does not comply with these terms. 